Supporting Information for

\title{
Exploring the Local Determinants of SARS-CoV-2 Transmission and Control via an
}

\section{Exposure-Based Model}

Qu Cheng ${ }^{a^{*}}$, Robert C. Spear ${ }^{a}$

${ }^{a}$ Division of Environmental Health Sciences, School of Public Health, University of California, Berkeley, CA

94720, USA.

*qcheng@berkeley.edu

Number of pages: 31

Number of figures: 5

Number of tables: 2 


\section{S1 Text: Generating the synthetic population}

\section{Demographics}

The synthetic population for the target community was generated with the 2018 5-year American Community Survey (ACS) and Public Use Microdata Sample (PUMS) data by using the iterative proportional updating (IPU) algorithm ${ }^{1}$. IPU reweights household and individual samples in the individual-level census data (PUMS) with a heuristic iterative procedure to generate a synthetic population whose marginal distributions of the attributes of interest match those reported in the aggregated census data (ACS). The matched attributes including sex, age group, grade level for 3 years and older, occupation group for 16 years and older, travel mode to work, and household level income. The R package ipfr was used to implement the IPU algorithm ${ }^{2}$. A total of 211,412 persons were generated for the city of Modesto.

\section{Assigning home, workplace, classroom, and car to each individual}

Each household was assigned to a home environment with various size based on its size and household income. Three categories of home size were used in the simulation: small (45-85 $\left.\mathrm{m}^{2}\right)$, medium $\left(85-200 \mathrm{~m}^{2}\right)$, and large (200-275 $\left.\mathrm{m}^{2}\right)$ home. The probability of being assigned to each category is shown in Table ST1.1.

Table ST1.1. Probabilities of being assigned to small, medium and large home as a function of household size and annual household income.

\begin{tabular}{ccccc}
\hline Household size & Household income (\$) & \multicolumn{3}{c}{ Probability of being assigned to a } \\
medium home & large home \\
\hline \multirow{2}{*}{$1-2$} & $<50,000$ & 0.8 & 0.15 & 0.05 \\
& $50,000-75,000$ & 0.5 & 0.45 & 0.05 \\
\multirow{2}{*}{$3-5$} & $>75,000$ & 0.5 & 0.45 & 0.05 \\
& $<50,000$ & 0.6 & 0.3 & 0.1 \\
& $50,000-75,000$ & 0.3 & 0.6 & 0.1 \\
\multirow{2}{*}{$6+$} & $>75,000$ & 0.1 & 0.7 & 0.2 \\
\hline & $<50,000$ & 0.25 & 0.75 & 0.2 \\
& $50,000-75,000$ & 0.05 & 0.4 & 0.55 \\
\hline
\end{tabular}

Each employed individual was assigned to a workplace based on their occupation group. Table S2 shows the probability of being assigned to each environment type by occupation group. After being assigned an environment type, each person was further randomly assigned to work in a specific environment in that environment type. The methods to simulate environments in the target community are described in S3 Text.

The total number of cars in Modesto was obtained from 2018 ACS 5-yr estimates detailed table B08201. Then each person was assigned a car randomly.

For those students in preschools and grades 1-6, a specific school environment in the corresponding grade level was assigned randomly to them, assuming that children in the lower grades do not change classrooms.

\section{Inhalation rates}

Each person was assigned a baseline inhalation rate with a truncated normal distribution according to the EPA exposure handbook ${ }^{3}$ based on their sex and age group. The parameters for the truncated normal distribution are shown in Table ST1.2. The inhalation rate during sleep is assumed to be 0.64 times the baseline rate, while that during working is assumed to vary with occupation category (Table ST1.3).

Table ST1.2 Parameters for the baseline inhalation rate distributions based on age and sex.

Age group Sex
Inhalation rate $\left(\mathrm{m}^{3} / \mathrm{hour}\right)$ 


\begin{tabular}{cccccc}
\hline & & Lowest & Highest & Mean & Standard deviation \\
\hline$<10$ & 0.30 & 1.92 & 0.83 & 0.28 \\
$10-17$ & 0.18 & 2.10 & 1.06 & 0.40 \\
$>17$ & Male & 0.138 & 1.67 & 0.83 & 0.37 \\
& Female & 0.25 & 1.76 & 0.49 & 0.15 \\
\hline
\end{tabular}

Table ST1.3 Scaling factors for males and females during work based on occupation categories.

\begin{tabular}{|c|c|c|c|c|c|}
\hline \multirow{2}{*}{ Occupation category } & \multicolumn{3}{|c|}{ Time with different activity level (\%) } & \multicolumn{2}{|c|}{ Scaling factor for } \\
\hline & Light & Moderate & Heavy & Male & Female \\
\hline Management occupations & 100 & & & 0.8 & 0.5 \\
\hline $\begin{array}{l}\text { Business and financial operations } \\
\text { occupations }\end{array}$ & 100 & & & 0.8 & 0.5 \\
\hline Computer and mathematical occupations & 100 & & & 0.8 & 0.5 \\
\hline Architecture and engineering occupations & 100 & & & 0.8 & 0.5 \\
\hline $\begin{array}{l}\text { Life, physical, and social science } \\
\text { occupations }\end{array}$ & 100 & & & 0.8 & 0.5 \\
\hline Community and social service occupations & 100 & & & 0.8 & 0.5 \\
\hline Legal occupations & 100 & & & 0.8 & 0.5 \\
\hline $\begin{array}{l}\text { Educational instruction, and library } \\
\text { occupations }\end{array}$ & 100 & & & 0.8 & 0.5 \\
\hline $\begin{array}{l}\text { Arts, design, entertainment, sports, and } \\
\text { media occupations }\end{array}$ & 70 & 20 & 10 & 1.54 & 0.96 \\
\hline $\begin{array}{l}\text { Health diagnosing and treating practitioners } \\
\text { and other technical occupations; Health } \\
\text { technologists and technicians }\end{array}$ & 100 & & & 0.8 & 0.5 \\
\hline Healthcare support occupations & 80 & 20 & & 1.14 & 0.72 \\
\hline $\begin{array}{l}\text { Firefighting and prevention, and other } \\
\text { protective service workers including } \\
\text { supervisors; Law enforcement workers } \\
\text { including supervisors }\end{array}$ & 70 & 20 & 10 & 1.54 & 0.96 \\
\hline $\begin{array}{l}\text { Food preparation and serving related } \\
\text { occupations }\end{array}$ & 90 & 10 & & 0.97 & 0.61 \\
\hline $\begin{array}{l}\text { Building and grounds cleaning and } \\
\text { maintenance occupations }\end{array}$ & 50 & 50 & & 1.65 & 1.05 \\
\hline $\begin{array}{l}\text { Personal care and service occupations } \\
\text { Sales and related occupations }\end{array}$ & $\begin{array}{c}80 \\
100\end{array}$ & 20 & & $\begin{array}{c}1.14 \\
0.8\end{array}$ & $\begin{array}{l}0.72 \\
0.5\end{array}$ \\
\hline $\begin{array}{l}\text { Office and administrative support } \\
\text { occupations }\end{array}$ & 100 & & & 0.8 & 0.5 \\
\hline Farming, fishing, and forestry occupations & 30 & 50 & 20 & 2.45 & 1.53 \\
\hline Construction and extraction occupations & 20 & 70 & 10 & 2.35 & 1.51 \\
\hline $\begin{array}{l}\text { Installation, maintenance, and repair } \\
\text { occupations }\end{array}$ & 70 & 30 & & 1.31 & 0.83 \\
\hline Production occupations & 40 & 60 & & 1.82 & 1.16 \\
\hline Transportation occupations & 70 & 30 & & 1.31 & 0.83 \\
\hline Material moving occupations & 30 & 60 & 10 & 2.22 & 1.4 \\
\hline
\end{tabular}




\section{S2 Text: Visits to environments}

Each person in the synthetic population is assumed to visit different environments and stay for various durations in each environment. The environment visited by each individual and the timing of the visits were determined stochastically by assigning the daily activities of a random sampled respondent of the American Time Use Survey (ATUS) if the individual is $\geq 15$ years old) ${ }^{4}$ and the Child Development Supplement of the Panel Study of Income Dynamics (PSID) if the individual is $<15$ years old ${ }^{5}$ matching on age, sex, employment status, and weekday. A random 5/7 of the synthetic population was assumed to weekday activities, while the other 2/7 was assumed to have weekend activities.

Each daily activity was then assigned to an environment category based on the location information recorded by ATUS and PSID based on Tables ST2.1 and ST2.2. We further assigned a specific environment in that environment category to the activity randomly with a probability proportional to the floor area of the specific environments (except for Home, Office, Personal transportation, and School environments with fixed rooms, which are fixed for each person), based on the assumption that larger environments tend to attract more visits.

Table ST2.1. Mapping relationship between ATUS locations and environment categories

\begin{tabular}{|c|c|c|}
\hline ATUS ID ${ }^{a}$ & ATUS location name ${ }^{b}$ & Environment category \\
\hline 1 & Respondent's home or yard & Home \\
\hline 2 & Respondent's workplace & Workplace \\
\hline 3 & Someone else's home & Others' home \\
\hline 4 & Restaurant or bar & Restaurant or bar \\
\hline 5 & Place of worship & $\begin{array}{c}\text { Other public places: long visiting time (large, medium, } \\
\text { small) }\end{array}$ \\
\hline 6 & Grocery store & Grocery store \\
\hline 7 & Other store/mall & Other store/mall (large, medium, small) \\
\hline 8 & School & School \\
\hline 9 & Outdoors away from home & Outdoor \\
\hline 10 & Library & $\begin{array}{l}\text { Other public places: long visiting time (large, medium, } \\
\text { small) }\end{array}$ \\
\hline 11 & Other place & N/A \\
\hline 12 & Car, truck, or motorcycle (driver) & $\begin{array}{l}\text { If this and } 7 \text { for transportation mode, then outdoor; } \\
\text { otherwise personal transportation }\end{array}$ \\
\hline 13 & Car, truck, or motorcycle (passenger) & $\begin{array}{l}\text { If this and } 7 \text { for transportation mode, then outdoor; } \\
\text { otherwise personal transportation }\end{array}$ \\
\hline 14 & Walking & Outdoor \\
\hline 15 & Bus & Bus \\
\hline 16 & Subway/train & Train \\
\hline 17 & Bicycle & Outdoor \\
\hline 18 & Boat/ferry & N/A \\
\hline 19 & Taxi/limousine service & Taxi/carpool \\
\hline 20 & Airplane & N/A \\
\hline 21 & Other mode of transportation & N/A \\
\hline 30 & Bank & $\begin{array}{c}\text { Other public places: short visiting time (large, medium, } \\
\text { small) }\end{array}$ \\
\hline 31 & Gym/health club & $\begin{array}{l}\text { Other public places: long visiting time (large, medium, } \\
\text { small) }\end{array}$ \\
\hline 32 & Post Office & $\begin{array}{c}\text { Other public places: short visiting time (large, medium, } \\
\text { small) }\end{array}$ \\
\hline 89 & Unspecified place & $N / A$ \\
\hline 99 & $\begin{array}{l}\text { Unspecified mode of transportation } \\
\text { not collected for activities with activity }\end{array}$ & N/A \\
\hline$-1,-2,-3$ & $\begin{array}{c}\text { codes of } 0101 \times x, 0102 x x, 0104 x x \\
500105, \text { or } 500106\end{array}$ & $0101 x x, 0102 x x, 0104 x x$ to Home \\
\hline
\end{tabular}

a TEWHERE_ID column in ATUS data

b TEWHERE_PLACE column in ATUS data 
Table ST2.2. Mapping relationship between PSID locations and environment types

\begin{tabular}{|c|c|c|}
\hline PSID ID a & PSID location name ${ }^{b}$ & Environment type \\
\hline 10 & Home or yard & Home \\
\hline 20 & Transit (car, bus, walking, biking) & $\begin{array}{c}\text { Personal transportation, bus, train, taxi/carpool, } \\
\text { outdoor }\end{array}$ \\
\hline 30 & Parent's place of work & Workplace \\
\hline 35 & Child's place of work & Workplace \\
\hline 40 & $\begin{array}{l}\text { Someone else's home; at neighbor's or } \\
\text { babysitter's or home-based day care }\end{array}$ & Others' home \\
\hline 45 & Child's other parent's home & Others' home \\
\hline 50 & $\begin{array}{l}\text { Restaurants, bars, fast-food places and their } \\
\text { parking lots }\end{array}$ & Restaurant or bar \\
\hline 60 & $\begin{array}{c}\text { Indoor recreational place (theatres, youth } \\
\text { recreation center) }\end{array}$ & $\begin{array}{l}\text { Other public places: long visiting time (large, } \\
\text { medium, small) }\end{array}$ \\
\hline 70 & $\begin{array}{c}\text { Outdoor recreational place (parks, } \\
\text { neighborhood) }\end{array}$ & 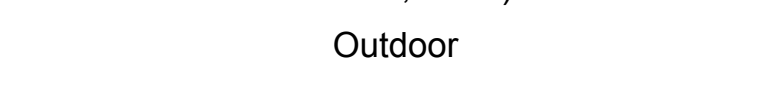 \\
\hline 80 & School (includes college) & $\begin{array}{l}\text { School } \\
\text { S }\end{array}$ \\
\hline 81 & Church or other place of worship & $\begin{array}{l}\text { Other public places: long visiting time (large, } \\
\text { medium, small) }\end{array}$ \\
\hline 82 & Store/shopping center/mall & $\begin{array}{c}\text { Grocery store; Other store/mall (large, medium, } \\
\text { small) }\end{array}$ \\
\hline 83 & Non-retail business (banks, offices, library) & $\begin{array}{c}\text { Other public places: long visiting time (large, } \\
\text { medium, small); Other public places: short visiting } \\
\text { time (large, medium, small) }\end{array}$ \\
\hline 84 & Daycare center (not home-based day care) & School \\
\hline 97 & Other, hospital, parking structure & $\mathrm{N} / \mathrm{A}$ \\
\hline 99 & NA; refused & $\mathrm{N} / \mathrm{A}$ \\
\hline 0 & $\begin{array}{l}\text { Activity was personal, private, school, or } \\
\text { work }\end{array}$ & $\mathrm{N} / \mathrm{A}$ \\
\hline
\end{tabular}

a COLD_14 column in PSID data

b Answer to the Question "Where were you" PSID data 


\section{S3 Text: Environment generation}

We simulated 10 categories and 39 subcategories of environments as listed below including schools with fixed rooms (staff office, preschool, grades 1-6), school with rotating rooms (grades 7-16), transportation (bus, taxi/carpool, and personal transportation), outdoor environments, other environments with long visit times (small, medium, large), and other environments with short visit times (small, medium, large). We first roughly estimated the number of each environment in the target community using census data, Google Maps, and Yelp. Then for each environment, several attributes-including its floor area, height, ventilation flow rate-were assigned to them by sampling from predefined distributions (Table ST3.1). These attributes were used to estimate the virus concentration in the environments.

Table ST3.1 Characteristics of different environment categories

\begin{tabular}{|c|c|c|c|c|c|}
\hline Category & Subcategory & $\begin{array}{c}\text { Number of } \\
\text { environments }\end{array}$ & $\begin{array}{c}\text { Floor area } \\
\left(\mathrm{m}^{2}\right)\end{array}$ & Height (m) & AER \\
\hline \multirow{3}{*}{ Home } & $S$ & \multirow{3}{*}{$\begin{array}{l}\text { According to the } \\
\text { simulated synthetic } \\
\text { population ( } 1 \text { 1 Text) }\end{array}$} & $U(45-85)$ & $\begin{array}{c}\text { Truncnorm }(\text { low }=2.13, \text { high } \\
=3.35, \text { mean }=2.45, \mathrm{sd}= \\
0.1)\end{array}$ & $0.5-1$ \\
\hline & M & & $U(85-200)$ & $\begin{array}{c}\text { Truncnorm }(\text { low }=2.13, \text { high } \\
=3.35, \text { mean }=2.55, \mathrm{sd}= \\
0.1)\end{array}$ & $0.5-1.2$ \\
\hline & L & & $U(200-275)$ & $\begin{array}{c}\text { Truncnorm }(\text { low }=2.13, \text { high } \\
=3.35, \text { mean }=2.65, \mathrm{sd}= \\
0.1)\end{array}$ & $0.5-1.5$ \\
\hline \multirow{8}{*}{$\begin{array}{l}\text { School with } \\
\text { fixed rooms } \\
\text { (SchoolFix) }\end{array}$} & Staff office & $776^{c}$ & $U(23.2,55.7)$ & $\begin{array}{c}\text { Truncnorm }(\text { low }=2.7, \text { mean } \\
=3.048, \mathrm{sd}=0.2)\end{array}$ & $1-3$ \\
\hline & Preschool & $1140^{a}$ & $U(23.2,55.7)$ & $\begin{array}{c}\text { Truncnorm }(\text { low }=2.45 \text {, mean } \\
=2.89, \mathrm{sd}=0.3)\end{array}$ & $0.7-3.3$ \\
\hline & Grade 1 & $129^{b}$ & $U(23.2,55.7)$ & $\begin{array}{c}\text { Truncnorm(low }=2.45, \text { mean } \\
=2.89, \mathrm{sd}=0.3)\end{array}$ & $0.7-3.3$ \\
\hline & Grade 2 & $116^{b}$ & $U(23.2,55.7)$ & $\begin{array}{c}\text { Truncnorm }(\text { low }=2.45 \text {, mean } \\
=2.89, \text { sd }=0.3)\end{array}$ & $0.7-3.3$ \\
\hline & Grade 3 & $118^{b}$ & $U(23.2,55.7)$ & $\begin{array}{c}\text { Truncnorm(low }=2.45, \text { mean } \\
=2.89, \mathrm{sd}=0.3)\end{array}$ & $0.7-3.3$ \\
\hline & Grade 4 & $123^{b}$ & $U(23.2,55.7)$ & $\begin{array}{c}\text { Truncnorm }(\text { low }=2.45 \text {, mean } \\
=2.89, \mathrm{sd}=0.3)\end{array}$ & $0.7-3.3$ \\
\hline & Grade 5 & $131^{b}$ & $\mathrm{U}(23.2,55.7)$ & $\begin{array}{c}\text { Truncnorm }(\text { low }=2.45, \text { mean } \\
=2.89, \mathrm{sd}=0.3)\end{array}$ & $0.7-3.3$ \\
\hline & Grade 6 & $134^{b}$ & $\mathrm{U}(23.2,55.7)$ & $\begin{array}{c}\text { Truncnorm }(\text { low }=2.45, \text { mean } \\
=2.89, \mathrm{sd}=0.3)\end{array}$ & $0.7-3.3$ \\
\hline \multirow{8}{*}{$\begin{array}{l}\text { School with } \\
\text { rotating rooms } \\
\text { (SchoolRotate) }\end{array}$} & Grade 7 & $126^{b}$ & $U(23.2,55.7)$ & $\begin{array}{c}\text { Truncnorm(low }=2.45, \text { mean } \\
=2.89, \mathrm{sd}=0.3)\end{array}$ & $0.7-3.3$ \\
\hline & Grade 8 & $140^{\mathrm{b}}$ & $U(23.2,55.7)$ & $\begin{array}{c}\text { Truncnorm }(\text { low }=2.45 \text {, mean } \\
=2.89, \mathrm{sd}=0.3)\end{array}$ & $0.7-3.3$ \\
\hline & Grade 9 & $121^{b}$ & $\mathrm{U}(23.2,55.7)$ & $\begin{array}{c}\text { Truncnorm }(\text { low }=2.45 \text {, mean } \\
=2.89, \mathrm{sd}=0.3)\end{array}$ & $0.7-3.3$ \\
\hline & Grade 10 & $105^{b}$ & $\mathrm{U}(23.2,55.7)$ & $\begin{array}{c}\text { Truncnorm }(\text { low }=2.45, \text { mean } \\
=2.89, \text { sd }=0.3)\end{array}$ & $0.7-3.3$ \\
\hline & Grade 11 & $113^{b}$ & $\mathrm{U}(23.2,55.7)$ & $\begin{array}{c}\text { Truncnorm(low }=2.45, \text { mean } \\
=2.89, \mathrm{sd}=0.3)\end{array}$ & $0.7-3.3$ \\
\hline & Grade 12 & $134^{b}$ & $\mathrm{U}(23.2,55.7)$ & $\begin{array}{c}\text { Truncnorm }(\text { low }=2.45, \text { mean } \\
=2.89, \text { sd }=0.3)\end{array}$ & $0.7-3.3$ \\
\hline & Grade 13 & $127^{b}$ & $\mathrm{U}(23.2,55.7)$ & $\begin{array}{c}\text { Truncnorm(low }=2.45, \text { mean } \\
=2.89, \mathrm{sd}=0.3)\end{array}$ & $0.7-3.3$ \\
\hline & Grade 14 & $136^{b}$ & $\mathrm{U}(23.2,55.7)$ & $\begin{array}{c}\text { Truncnorm(low }=2.45, \text { mean } \\
=2.89, \mathrm{sd}=0.3)\end{array}$ & $0.7-3.3$ \\
\hline
\end{tabular}




\begin{tabular}{|c|c|c|c|c|c|}
\hline & Grade 15 & $522^{b}$ & $U(23.2,55.7)$ & $\begin{array}{c}\text { Truncnorm(low }=2.45, \text { mean } \\
=2.89, \mathrm{sd}=0.3)\end{array}$ & $0.7-3.3$ \\
\hline & Grade 16 & $53^{b}$ & $U(23.2,55.7)$ & $\begin{array}{c}\text { Truncnorm }(\text { low }=2.45 \text {, mean } \\
=2.89, \mathrm{sd}=0.3)\end{array}$ & $0.7-3.3$ \\
\hline \multirow{3}{*}{ Office } & $S$ & $10000^{d}$ & $U(7.4,18.6)$ & $\begin{array}{c}\text { Truncnorm (low }=2.4, \text { mean } \\
=2.44, \text { sd }=0.1)\end{array}$ & $1-3$ \\
\hline & M & $5000^{d}$ & $U(23.2,55.7)$ & $\begin{array}{c}\text { Truncnorm (low }=2.7 \text {, mean } \\
=3.048, \mathrm{sd}=0.2)\end{array}$ & $1-3$ \\
\hline & L & $2000^{d}$ & $\begin{array}{c}\mathrm{U}(139.4 \\
232.3)\end{array}$ & $\begin{array}{c}\text { Truncnorm }(\text { low }=2.7, \text { mean } \\
=3.048, \mathrm{sd}=0.2)\end{array}$ & $2-3$ \\
\hline \multirow{4}{*}{ Retail } & Grocery store & $120^{e}$ & $U(100,2000)$ & $\begin{array}{c}\text { Truncnorm(low }=3.65, \text { mean } \\
=4.26, \text { sd }=0.3)\end{array}$ & $1-3$ \\
\hline & Other S & $50^{e}$ & $U(100,232.3)$ & $\begin{array}{c}\text { Truncnorm }(\text { low }=3.04, \text { mean } \\
=3.65, \mathrm{sd}=0.1)\end{array}$ & $0.5-3$ \\
\hline & Other M & $50^{e}$ & $U(232,2000)$ & $\begin{array}{c}\text { Truncnorm }(\text { low }=3.65, \text { mean } \\
=4.572, \mathrm{sd}=0.2)\end{array}$ & $1-3$ \\
\hline & Other $\mathrm{L}$ & $20^{e}$ & $U(2000,5000)$ & $\begin{array}{c}\text { Truncnorm }(\text { low }=3.65 \text {, mean } \\
=4.88, \mathrm{sd}=0.3)\end{array}$ & $1-3$ \\
\hline \multirow{3}{*}{ Transportation } & Bus & $103^{f}$ & $U(14,45)$ & $\begin{array}{c}\text { Truncnorm(mean }=2.2, \mathrm{sd}= \\
0.15)\end{array}$ & $1-4$ \\
\hline & Taxi/Carpool & $1000^{\mathrm{g}}$ & $\begin{array}{l}\text { Normal }(3 \\
\left.0.2^{2}\right)\end{array}$ & $\operatorname{Norm}($ mean $=1.2, \mathrm{sd}=0.05)$ & $0.5-3$ \\
\hline & $\begin{array}{l}\text { Personal } \\
\text { transportation }\end{array}$ & $132193^{h}$ & $\begin{array}{l}\text { Normal }(3 \\
\left.0.2^{2}\right)\end{array}$ & $\operatorname{Norm}(\operatorname{mean}=1.2, \mathrm{sd}=0.05)$ & $0.5-3$ \\
\hline $\begin{array}{l}\text { Indoor } \\
\text { restaurants } \\
\text { and bars } \\
\text { (IndoorBnR) }\end{array}$ & & $240^{i}$ & $\mathrm{U}(23.2,232.3)$ & $\begin{array}{c}\text { Truncnorm }(\text { low }=2.13, \text { high } \\
=3.35, \text { mean }=2.65, \text { sd }= \\
0.1)\end{array}$ & $4-8$ \\
\hline Outdoor & & $100000^{d}$ & $\mathrm{~N} / \mathrm{A}$ & $\mathrm{N} / \mathrm{A}$ & Inf \\
\hline \multirow{3}{*}{$\begin{array}{l}\text { Other } \\
\text { environments: } \\
\text { long visiting } \\
\text { time (OtherL) }\end{array}$} & $S$ & $150^{e}$ & $U(7.4,18.6)$ & $\begin{array}{c}\text { Truncnorm(low }=2.4, \text { mean } \\
=2.44, \mathrm{sd}=0.1)\end{array}$ & $1-3$ \\
\hline & $M$ & $330^{e}$ & $\mathrm{U}(23.2,55.7)$ & $\begin{array}{c}\text { Truncnorm }(\text { low }=2.7, \text { mean } \\
=3.048, \mathrm{sd}=0.2)\end{array}$ & $2-3$ \\
\hline & L & $280^{e}$ & $\begin{array}{c}U(139.4 \\
232.3)\end{array}$ & $\begin{array}{c}\text { Truncnorm(low }=2.7 \text {, mean } \\
=3.048, \mathrm{sd}=0.2)\end{array}$ & $2-3$ \\
\hline \multirow{3}{*}{$\begin{array}{l}\text { Other } \\
\text { environments: } \\
\text { Short visiting } \\
\text { time (OtherS) }\end{array}$} & $S$ & $20^{e}$ & $\cup(7.4,18.6)$ & $\begin{array}{c}\text { Truncnorm(low }=2.4, \text { mean } \\
=2.44, \mathrm{sd}=0.1)\end{array}$ & $2-3$ \\
\hline & M & $40^{e}$ & $U(23.2,55.7)$ & $\begin{array}{c}\text { Truncnorm }(\text { low }=2.7 \text {, mean } \\
=3.048, \mathrm{sd}=0.2)\end{array}$ & $2-3$ \\
\hline & L & $20^{e}$ & $\begin{array}{l}\mathrm{U}(139.4 \\
232.3)\end{array}$ & $\begin{array}{c}\text { Truncnorm }(\text { low }=2.7, \text { mean } \\
=3.048, \mathrm{sd}=0.2)\end{array}$ & $2-3$ \\
\hline
\end{tabular}

a Assuming 10 students per class

${ }^{\mathrm{b}}$ Assuming 25 students per class

c Assuming 2 teachers on average for each classroom and 6 teachers sharing an office

d Rough estimates

e From Google Map

f 61 buses (https://www.modestoareaexpress.com/) and 42 school buses (https://bit.ly/3tbDcQp)

9 Estimated by assuming 0.5 taxi per 1,000 population ${ }^{6}$

${ }^{\mathrm{h}}$ From 2018 ACS 5-yr estimates detailed tables B08201

i From Yelp 


\section{S4 Text: Attributing initial cases to different sex, age, and symptom groups}

We first estimated the number of COVID-19 cases $N_{\text {inf }}$ according to a predefined prevalence rate $p$ (including both symptomatic and asymptomatic cases) as $N_{\text {inf }}=\operatorname{round}(N * p)$, where $N$ is the total population size of the community. We then attributed these cases to different age-sex groups according to a seroprevalence survey conducted in San Francisco ${ }^{7}$, and different symptom groups (i.e., asymptomatic, presymtomatic, and symptomatic) according to the probability of being symptomatic in each age group and the duration of the presymptomatic and symptomatic period. Symptomatic cases were assumed to staying home for the whole simulated day, while asymptomatic and presymptomatic cases can visit all environments as can susceptibles.

\section{Attributing to age and sex groups}

The cases were attributed to different age and sex groups based on the results of a seroprevalence survey ${ }^{7}$, which present the number of people tested positive $\left(k_{i}\right)$ and the total tests $\left(n_{i}\right)$ by age $(4-10,11-17,18-50,51$ 70 , and $>70$ ) and sex groups (male, female). Since there no participants were under 4 , we assumed that the prevalence rate in under 4 is 0.

We first sampled the prevalence rate in each age group from a normal distribution with a mean of $g_{i}=k_{i} / n_{i}$ and a variance of $g_{i}\left(1-g_{i}\right) / n_{i}$, then adjust this seroprevalence for testing performance by $p_{i}=$ $\max \left(0, q_{i}+\right.$ specificity -1$) /($ sensitivity + specificity -1$\left.)\right)$ following ${ }^{7}$. The number of cases in each age group in the synthetic population was calculated by multiplying the prevalence rate in that age group and the population size in the same age group in the synthetic population. The case count for males and females in the synthetic population was calculated the same way. By assuming independence between age and sex, the number of cases in each age and sex group can be calculated easily as the product of the prevalence rate in that age group and the proportion of cases for that sex group. These case counts were then converted to the proportion of cases in each age-sex group, which were then used as the success probabilities of a multinomial distribution with $N_{\text {inf }}$ trails for sampling the cases in each age-sex group in the synthetic population. This step was taken to adjust the prevalence rate in the seroprevalence survey to our predefined prevalence rate.

\section{Attributing to symptom groups}

According to a previous study, the proportion of asymptomatic COVID cases varies with age, but not sex ${ }^{8}$. Therefore, for each case, we first sampled if it was asymptomatic based from a binomial distribution with a success rate varies by the age of this case. The age-dependent proportion of asymptomatic cases was obtained from ${ }^{8}$. For a case that finally becomes symptomatic (including both pre-symptomatic and symptomatic cases), whether or not they are pre-symptomatic was also sampled from a binomial distribution. The probability of being pre-symptomatic was estimated as the ratio of the duration of pre-symptomatic period to the duration of pre-symptomatic and symptomatic period. The distribution of the durations of the presymptomatic and symptomatic periods were obtained from ${ }^{9}$. 


\section{S5 Text: Determining the probability of near-field exposure and the proportion of time having near-field exposure given exposed in the near field}

Since two persons co-occupying the same environment do not necessarily have close contacts that lead to near-field exposure, we first sampled if they had close contact from a Bernoulli distribution with a success rate $p_{x, y, k}$. The $p_{x, y, k}$ for each environmental category and each visiting/working status and the reasons for setting the value is shown in Table ST5.1. If $x$ and $y$ did have close contact in environment $k$ according to the sampling result, the proportion of their overlapping time in the environment $f_{x, y, k}$ was sampled from a uniform distribution. The parameters for the distributions and the reasons for setting them are shown in Table ST5.1. Since the probability of close contacts and the duration of the close contacts are likely to be different for encounters between two visitors to the environment, one visitor and one person working in the environment, and two persons working in the environment, we specified different $p_{x, y, k}$ and $f_{x, y, k}$ for these three categories. 
Table ST5.1 The probability of near-field exposure $p_{x, y, k}$ and the proportion of time in the near field given near-field exposure $f_{x, y, k}$ for different environment categories. The numbers in the brackets represent the range of the parameters.

\begin{tabular}{|c|c|c|c|c|c|c|c|}
\hline & & \multicolumn{2}{|c|}{ Non-workplace \& Non-workplace } & \multicolumn{2}{|c|}{ Workplace \& Non-workplace } & \multicolumn{2}{|c|}{ Workplace \& Workplace } \\
\hline & & $p_{x, y, k}$ & $\boldsymbol{f}_{x, y, k}$ & $\boldsymbol{p}_{x, y, k}$ & $f_{x, y, k}$ & $p_{x, y, k}$ & $f_{x, y, k}$ \\
\hline & S & 1 & $\begin{array}{c}{[0.57,0.97]} \\
0.77 \text { for a typical } \\
\text { household with a couple; } \\
\text { spending } 13 \text { hours at } \\
\text { home among which } 10 \\
\text { hours are together, } \\
\text { including sleeping time, } \\
\text { time for breakfast and } \\
\text { dinner, and a short } \\
\text { amount of other time }\end{array}$ & 1 & $\begin{array}{c}{[0.57,0.97]} \\
0.77 \text { for a typical } \\
\text { household with a couple; } \\
\text { spending } 13 \text { hours at } \\
\text { home among which } 10 \\
\text { hours are together, } \\
\text { including sleeping time, } \\
\text { time for breakfast and } \\
\text { dinner, and a short } \\
\text { amount of other time }\end{array}$ & 1 & $\begin{array}{c}\text { [0.3, 0.7] } \\
0.5 \text { for a typical } \\
\text { household with a } \\
\text { couple; spending } 22 \\
\text { hours at home among } \\
\text { which } 11 \text { hours are } \\
\text { together, including } \\
\text { sleeping time, time for } \\
\text { breakfast, lunch and } \\
\text { dinner, and a short } \\
\text { amount of other time }\end{array}$ \\
\hline Home & M & 1 & $\begin{array}{c}{[0.345,0.745]} \\
0.545=0.5 \text { (probability of } \\
\text { the infector is one of the } \\
\text { adult) })^{\star}\left(0.77+2^{\star} 0.5\right) / 3+ \\
0.5^{*}\left(0.5^{\star} 3\right) / 3 \text { for a typical } \\
\text { household with } 1 \text { couple }+ \\
2 \text { kids; assuming } 0.77 \text { for } \\
\text { the adults as in the above } \\
\text { cell, and } 0.5 \text { for kids by } \\
\text { assuming they spend } 16 \\
\text { hours at home each day } \\
\text { and do not sleep with } \\
\text { parents }\end{array}$ & 1 & $\begin{array}{c}{[0.345,0.745]} \\
0.545=0.5 \text { (probability of } \\
\text { the infector is one of the } \\
\text { adult) }\left(0.77+2^{*} 0.5\right) / 3+ \\
0.5^{*}\left(0.5^{*} 3\right) / 3 \text { for a typical } \\
\text { household with } 1 \text { couple }+ \\
2 \text { kids; assuming } 0.77 \text { for } \\
\text { the adults as in the above } \\
\text { cell, and } 0.5 \text { for kids by } \\
\text { assuming they spend } 16 \\
\text { hours at home each day } \\
\text { and do not sleep with } \\
\text { parents }\end{array}$ & 1 & $\begin{array}{c}\text { [0.3, } 0.7] \\
0.5 \text { for a typical } \\
\text { household with } 1 \\
\text { couple }+2 \text { kids; } \\
\text { assuming } 0.5 \text { for the } \\
\text { adults as in the above } \\
\text { cell, and } 0.5 \text { for kids } \\
\text { by assuming they } \\
\text { spend } 16 \text { hours at } \\
\text { home each day and } \\
\text { do not sleep with } \\
\text { parents }\end{array}$ \\
\hline & L & 1 & $\begin{array}{c}{[0.313,0.713]} \\
0.513=2 / 7 \text { (probability of } \\
\text { the infector is one of the } \\
\text { couple })^{*}\left(0.77+5^{*} 0.5\right) / 6+ \\
5 / 7^{*}\left(0.5^{*} 6\right) / 6 \text { for a typical } \\
\text { household with } 3 \text { adults } \\
\text { (two of them are couple) }+ \\
3 \text { kids; assuming } 0.77 \text { for } \\
\text { the couple as in the } \\
\text { above cell, and } 0.5 \text { for } \\
\text { non-couple by assuming } \\
\text { they spend } 16 \text { hours at }\end{array}$ & 1 & $\begin{array}{c}{[0.313,0.713]} \\
0.513=2 / 7 \text { (probability of } \\
\text { the infector is one of the } \\
\text { couple })^{\star}\left(0.77+5^{*} 0.5\right) / 6+ \\
5 / 7^{\star}\left(0.5^{\star} 6\right) / 6 \text { for a typical } \\
\text { household with } 3 \text { adults } \\
\text { (two of them are couple) }+ \\
3 \text { kids; assuming } 0.77 \text { for } \\
\text { the couple as in the } \\
\text { above cell, and } 0.5 \text { for } \\
\text { non-couple by assuming } \\
\text { they spend } 16 \text { hours at }\end{array}$ & 1 & $\begin{array}{c}{[0.3,0.7]} \\
0.5=2 / 7 \text { (probability } \\
\text { of the infector is one } \\
\text { of the couple })^{*}(0.5+ \\
\left.5^{*} 0.5\right) / 6+ \\
5 / 7^{\star}\left(0.5^{*} 6\right) / 6 \text { for a } \\
\text { typical household with } \\
3 \text { adults (two of them } \\
\text { are couple }+3 \text { kids; } \\
\text { assuming } 0.5 \text { for the } \\
\text { couple as in the } \\
\text { above cell, and } 0.5 \text { for }\end{array}$ \\
\hline
\end{tabular}




$$
p_{x, y, k}
$$$$
p_{x, y, k}
$$$$
\text { home each day and do }
$$

\section{Prescho}

$$
\text { ol, }
$$

Grades

School 1-16,

and

Staff

offices

$$
\text { 2/number of }
$$
people assigned

to the class

$[0.9,1]$

$1 /$ number of

people in the

class

0

Assuming no visitors to the office. Offices with lots of visitors are included

in other places:

long/short durations
0
0
0
0

0 $p_{x, y, k}$

$\boldsymbol{f}_{\boldsymbol{x}, \boldsymbol{y}, \boldsymbol{k}}$

non-couple by

assuming they spend

16 hours at home

each day and do not

sleep with parents

$1 /$ number of

people

assigned to

the office

$[0.5,1]$

0 if no other

people; or

$1 /$ number of

people

$[0.8,1]$

assigned to

the office

0 if no other

people; or

$1 /$ number of

people

assigned to

the office

0 if no other

people; or

$1 /$ number of

people

assigned to

the office 
$p_{x, y, k}$

$f_{x, y, k}$

$[0, \min (0.06$,

$10 /$ total number of people with overlapping

Grocery visiting time with the infector)]

Meeting $6 \%$ of people (3 in 50) or at most 10

$[0, \min (0.06$,

Retail

Store

Other: S

\section{peotal number}

overlapping

visiting time with

the infector)]

Meeting $6 \%$ of

people (3 in 50) or

at most 10

\section{$[0, \min (0.06$,}

$10 /$ total number of

people with

overlapping

Other:

visiting time with

the infector)]

Meeting $6 \%$ of

people (3 in 50) or at most 10

\section{[0.0001, 0.04]}

0.017 : Assuming half a minitue in a $30 \mathrm{~min}$ visit

\section{$[0.0001,0.04]$}

0.017: Assuming half a minitue in a $30 \mathrm{~min}$ visit

$[0.1,0.2]$

\section{[0.0001, 0.04]}

0.017: Assuming half a minitue in a $30 \mathrm{~min}$ visit

$[0.1,0.2]$ $p_{x, y, k}$

$[0.01,0.1]$

0.05: Assuming 1.5 mins in a 30 min visit

$f_{x, y, k}$

$p_{x, y, k}$

[1/the total

number of

people

works in the

environment

, 0.25]

Assuming

meeting 1

person to up

to $25 \%$

persons

working in

the same

environment

[1/the total

number of

people

works in the

environment

$[0.01,0.1]$

0.05 : Assuming 1.5 mins

in a 30 min visit

, 0.25]

Assuming

meeting 1

person to up

to $25 \%$

persons

working in

the same

environment

[1/the total

number of

people

works in the

$[0.01,0.1]$

0.05 : Assuming 1.5 mins in a 30 min visit

$$
\text { 0.25] }
$$

Assuming meeting 1

person to up

to $25 \%$

persons

$[0.1,0.2]$

$[0.1,0.2]$ 
$p_{x, y, k}$

$f_{x, y, k}$ $f_{x, y, k}$

$p_{x, y, k}$

$\boldsymbol{f}_{\boldsymbol{x}, \boldsymbol{y}, \boldsymbol{k}}$

working in

the same

environment

$[0.0001,0.04]$

0.017: Assuming half a minitue in a 30 min visit

$[0, \min (0.06$,

$10 /$ total number of

people with

overlapping

Other: $\mathrm{L} \quad$ visiting time with

the infector)]

Meeting 6\% of

people (5 in 50) or

at most 10

$[0, \min (0.05$,

$5 /$ total number of people with

Public

transp

ortatio

n

Bus overlapping visiting time with

the infector)]

Meeting $5 \%$ of

people (1 in 20) or

at most 5
$[0.8,1]$

\section{$[0.8,1]$}

Almost everyone

has a short closecontact with the driver

[0.000001, 0.01]

0.005 : 10 seconds on average

May ignore this

since so short

$[0.01,0.1]$

0.05: Assuming 1.5 mins in a 30 min visit

\author{
[1/the total \\ number of \\ people \\ works in the \\ environment \\ , 0.25] \\ Assuming \\ meeting 1 \\ person to up \\ to $25 \%$ \\ persons \\ working in \\ the same \\ environment
}

$[0,0.1]$

\section{$[0.01,0.03]$}

Assuming 5-15 mins interaction during an $8 \mathrm{hr}$ shift 


\begin{tabular}{|c|c|c|c|c|c|c|c|}
\hline & & \multicolumn{2}{|c|}{ Non-workplace \& Non-workplace } & \multicolumn{2}{|c|}{ Workplace \& Non-workplace } & \multicolumn{2}{|c|}{ Workplace \& Workplace } \\
\hline & & $p_{x, y, k}$ & $\boldsymbol{f}_{x, y, k}$ & $\boldsymbol{p}_{x, y, k}$ & $f_{x, y, k}$ & $p_{x, y, k}$ & $f_{x, y, k}$ \\
\hline \multicolumn{8}{|l|}{$\begin{array}{l}\text { Perso } \\
\text { nal }\end{array}$} \\
\hline $\begin{array}{l}\text { transp } \\
\text { ortatio } \\
n\end{array}$ & & 1 & 1 & 1 & 1 & 1 & 1 \\
\hline $\begin{array}{l}\text { Indoor } \\
\text { restaur } \\
\text { ants } \\
\text { and } \\
\text { bars }\end{array}$ & & $\begin{array}{l}\text { 3/total number of } \\
\text { people with } \\
\text { overlapping } \\
\text { visiting time with } \\
\text { the infector }\end{array}$ & {$[0.9,1]$} & {$[0.1,0.2]$} & $\begin{array}{c}{[\mathbf{0 . 0 5}, \mathbf{0 . 1 7 ]}} \\
\text { 3-10 mins in a } 60 \text { mins } \\
\text { time }\end{array}$ & {$[0.1,0.75]$} & $\begin{array}{c}\text { [0.01, 0.125] } \\
\text { Assuming } 5 \text { mins to } \\
\text { an hour contact in a } \\
\text { 8-hr shift }\end{array}$ \\
\hline \multicolumn{2}{|l|}{$\begin{array}{l}\text { Outdo } \\
\text { or }\end{array}$} & $\begin{array}{l}\text { [0, } 5 / \text { total number } \\
\text { of people with } \\
\text { overlapping } \\
\text { visiting time with } \\
\text { the infector] }\end{array}$ & $\begin{array}{c}{[0.003,0.177]} \\
5 \text { seconds to } 5 \text { mins in an } \\
\text { average } 0.5 \text { hour } \\
\text { overlapping time }\end{array}$ & $\begin{array}{c}{[0,5 / \text { total }} \\
\text { number of } \\
\text { people with } \\
\text { overlapping } \\
\text { visiting time with } \\
\text { the infector] }\end{array}$ & $\begin{array}{c}{[\mathbf{0 . 0 0 3}, \mathbf{0 . 1 7 7 ]}} \\
5 \text { seconds to } 5 \text { mins in an } \\
\text { average } 0.5 \text { hour } \\
\text { overlapping time }\end{array}$ & $\begin{array}{c}\text { [0, } 5 / \text { total } \\
\text { number of } \\
\text { people } \\
\text { working in } \\
\text { the } \\
\text { environment } \\
\text { ] }\end{array}$ & {$[0.5,1]$} \\
\hline \multirow{3}{*}{$\begin{array}{l}\text { Other: } \\
\text { long } \\
\text { visiting } \\
\text { time }\end{array}$} & Small & $\begin{array}{l}\text { [0, } 2 \text { /total number } \\
\text { of people with } \\
\text { overlapping } \\
\text { visiting time with } \\
\text { the infector] }\end{array}$ & {$[0.8,1]$} & $\begin{array}{l}\text { [0.01-0.2] } \\
\text { Assuming } 5-100 \\
\text { employees }\end{array}$ & $\begin{array}{l}{[\mathbf{0 . 0 3}, \mathbf{0 . 3 3}]} \\
\text { Assuming } 2-20 \text { mins in a } \\
60 \text { min visit }\end{array}$ & $\begin{array}{l}{[0,1 / \text { number }} \\
\text { of people } \\
\text { assigned to } \\
\text { the office] }\end{array}$ & {$[0.8,1]$} \\
\hline & Medium & $\begin{array}{l}\text { [0, } 2 \text { /total number } \\
\text { of people with } \\
\text { overlapping } \\
\text { visiting time with } \\
\text { the infector] }\end{array}$ & {$[0.8,1]$} & {$[0.01-0.2]$} & $\begin{array}{c}{[\mathbf{0 . 0 3}, \mathbf{0 . 3 3}]} \\
\text { Assuming } 2-20 \text { mins in a } \\
60 \text { min visit }\end{array}$ & $\begin{array}{l}\text { [0, } 1 / \text { number } \\
\text { of people } \\
\text { assigned to } \\
\text { the office] }\end{array}$ & {$[0.8,1]$} \\
\hline & Large & $\begin{array}{l}{[0,2 / \text { total number }} \\
\text { of people with } \\
\text { overlapping } \\
\text { visiting time with } \\
\text { the infector] }\end{array}$ & {$[0.8,1]$} & {$[0.01-0.2]$} & $\begin{array}{l}{[\mathbf{0 . 0 3}, \mathbf{0 . 3 3}]} \\
\text { Assuming } 2-20 \text { mins in a } \\
60 \text { min visit }\end{array}$ & $\begin{array}{l}{[0,1 / \text { number }} \\
\text { of people } \\
\text { assigned to } \\
\text { the office }]\end{array}$ & {$[0.8,1]$} \\
\hline
\end{tabular}




\begin{tabular}{|c|c|c|c|c|c|c|c|}
\hline & & \multicolumn{2}{|c|}{ Non-workplace \& Non-workplace } & \multicolumn{2}{|c|}{ Workplace \& Non-workplace } & \multicolumn{2}{|c|}{ Workplace \& Workplace } \\
\hline & & $p_{x, y, k}$ & $f_{x, y, k}$ & $\boldsymbol{p}_{x, y, k}$ & $f_{x, y, k}$ & $p_{x, y, k}$ & $f_{x, y, k}$ \\
\hline \multirow{3}{*}{$\begin{array}{l}\text { Other: } \\
\text { short } \\
\text { visiting } \\
\text { time }\end{array}$} & Small & $\begin{array}{l}\text { [0, 2/total number } \\
\text { of people with } \\
\text { overlapping } \\
\text { visiting time with } \\
\text { the infector] }\end{array}$ & $\begin{array}{c}{[\mathbf{0 . 1 3}, \mathbf{0 . 8 7 ]}} \\
\text { Assuming } 2-13 \text { mins } \\
\text { waiting time during a } 15 \\
\text { mins visit }\end{array}$ & {$[0.01-0.2]$} & $\begin{array}{c}{[\mathbf{0 . 1 3}, \mathbf{0 . 6 7 ]}} \\
2-10 \text { mins in a } 15 \text { min visit }\end{array}$ & $\begin{array}{l}0 \text { if no other } \\
\text { people; or } \\
1 / \text { number of } \\
\text { people } \\
\text { assigned to } \\
\text { the office }\end{array}$ & {$[0.8,1]$} \\
\hline & Medium & $\begin{array}{l}\text { [0, } 2 / \text { total number } \\
\text { of people with } \\
\text { overlapping } \\
\text { visiting time with } \\
\text { the infector] }\end{array}$ & $\begin{array}{c}{[\mathbf{0 . 1 3}, \mathbf{0 . 8 7 ]}} \\
\text { Assuming } 2-13 \text { mins } \\
\text { waiting time during a } 15 \\
\text { mins visit }\end{array}$ & {$[0.01-0.2]$} & $\begin{array}{c}{[\mathbf{0 . 1 3}, \mathbf{0 . 6 7 ]}} \\
2-10 \text { mins in a } 15 \text { min visit }\end{array}$ & $\begin{array}{l}0 \text { if no other } \\
\text { people; or } \\
1 / \text { number of } \\
\text { people } \\
\text { assigned to } \\
\text { the office }\end{array}$ & {$[0.8,1]$} \\
\hline & Large & $\begin{array}{l}\text { [0, } 2 / \text { total number } \\
\text { of people with } \\
\text { overlapping } \\
\text { visiting time with } \\
\text { the infector] }\end{array}$ & $\begin{array}{c}{[\mathbf{0 . 1 3}, \mathbf{0 . 8 7 ]}} \\
\text { Assuming } 2-13 \text { mins } \\
\text { waiting time during a } 15 \\
\text { mins visit }\end{array}$ & {$[0.01-0.2]$} & $\begin{array}{c}{[\mathbf{0 . 1 3}, \mathbf{0 . 6 7 ]}} \\
2-10 \text { mins in a } 15 \text { min visit }\end{array}$ & $\begin{array}{l}0 \text { if no other } \\
\text { people; or } \\
1 / \text { number of } \\
\text { people } \\
\text { assigned to } \\
\text { the office }\end{array}$ & {$[0.8,1]$} \\
\hline
\end{tabular}


Table S1. Ranges for the calibrating parameters

\begin{tabular}{|c|c|c|c|}
\hline Parameter & Range & Distribution & Reference \\
\hline $\begin{array}{l}\text { Scaling parameter to adjust the emission rate for asymptomatic } \\
\text { cases } s_{a} \text { (Unitless) }\end{array}$ & $1.2-4.8$ & Uniform & 14,15 \\
\hline $\begin{array}{l}\text { Conversion factor between one quanta and one RNA copy } c_{i} \\
\text { (quanta/RNA copy) }\end{array}$ & $0-0.2$ & Uniform & 16 \\
\hline Virus loss rate from the near field $k_{1}$ (per hour) & $0.5-1$ & Uniform & 17 \\
\hline Inactivation rate of airborne viruses in the far field $k_{2}$ (per hour) & {$[0.63,0.9]^{*} \mathrm{k}_{1}$} & Uniform & 17 \\
\hline $\begin{array}{l}\text { Ratio of the airflow rate from the near to the far field to the air } \\
\text { exchange rate of the environment }\end{array}$ & $0.8-2$ & Uniform & $\begin{array}{l}\text { Our best } \\
\text { knowledge }\end{array}$ \\
\hline
\end{tabular}


Table S2. Probability of working in each environment subcategories by occupation group

\begin{tabular}{|c|c|c|c|c|c|c|c|c|c|c|}
\hline Occupation group & Home.s & Home.m & Home.I & School.G0 & School.G1 & School.G2 & School.G3 & School.G4 & School.G5 & School.G6 \\
\hline None & 0.1 & 0.1 & 0.1 & 0 & 0 & 0 & 0 & 0 & 0 & 0 \\
\hline Management occupations & 0 & 0 & 0 & 0 & 0 & 0 & 0 & 0 & 0 & 0 \\
\hline $\begin{array}{l}\text { Business and financial } \\
\text { operations occupations }\end{array}$ & 0 & 0 & 0 & 0 & 0 & 0 & 0 & 0 & 0 & 0 \\
\hline $\begin{array}{l}\text { Computer and mathematical } \\
\text { occupations }\end{array}$ & 0 & 0.1 & 0 & 0 & 0 & 0 & 0 & 0 & 0 & 0 \\
\hline $\begin{array}{l}\text { Architecture and engineering } \\
\text { occupations }\end{array}$ & 0 & 0.1 & 0 & 0 & 0 & 0 & 0 & 0 & 0 & 0 \\
\hline $\begin{array}{l}\text { Life, physical, and social } \\
\text { science occupations }\end{array}$ & 0 & 0.1 & 0 & 0 & 0 & 0 & 0 & 0 & 0 & 0 \\
\hline $\begin{array}{l}\text { Community and social service } \\
\text { occupations }\end{array}$ & 0 & 0 & 0 & 0 & 0 & 0 & 0 & 0 & 0 & 0 \\
\hline Legal occupations & & 0.1 & 0.1 & 0 & 0 & 0 & 0 & 0 & 0 & 0 \\
\hline $\begin{array}{l}\text { Educational instruction, and } \\
\text { library occupations }\end{array}$ & 0 & 0 & 0 & 0 & 0 & 0 & 0 & 0 & 0 & 0 \\
\hline $\begin{array}{l}\text { Arts, design, entertainment, } \\
\text { sports, and media } \\
\text { occupations }\end{array}$ & 0 & 0.1 & 0 & 0 & 0 & 0 & 0 & 0 & 0 & 0 \\
\hline $\begin{array}{l}\text { Health diagnosing and } \\
\text { treating practitioners and } \\
\text { other technical occupations; } \\
\text { Health technologists and } \\
\text { technicians }\end{array}$ & 0 & 0 & 0 & 0 & 0 & 0 & 0 & 0 & 0 & 0 \\
\hline $\begin{array}{l}\text { Healthcare support } \\
\text { occupations }\end{array}$ & 0 & 0 & 0 & 0 & 0 & 0 & 0 & 0 & 0 & 0 \\
\hline $\begin{array}{l}\text { Firefighting and prevention, } \\
\text { and other protective service } \\
\text { workers including } \\
\text { supervisors; Law enforcement } \\
\text { workers including supervisors }\end{array}$ & 0 & 0 & 0 & 0 & 0 & 0 & 0 & 0 & 0 & 0 \\
\hline $\begin{array}{l}\text { Food preparation and serving } \\
\text { related occupations }\end{array}$ & 0 & 0 & 0 & 0 & 0 & 0 & 0 & 0 & 0 & 0 \\
\hline $\begin{array}{l}\text { Building and grounds } \\
\text { cleaning and maintenance } \\
\text { occupations }\end{array}$ & 0 & 0 & 0 & 0 & 0 & 0 & 0 & 0 & 0 & 0 \\
\hline
\end{tabular}




\begin{tabular}{|c|c|c|c|c|c|c|c|c|c|c|}
\hline $\begin{array}{l}\text { Personal care and service } \\
\text { occupations }\end{array}$ & 0 & 0 & 0 & 0 & 0 & 0 & 0 & 0 & 0 & 0 \\
\hline Sales and related occupations & 0 & 0 & 0 & 0 & 0 & 0 & 0 & 0 & 0 & 0 \\
\hline $\begin{array}{l}\text { Office and administrative } \\
\text { support occupations }\end{array}$ & 0 & 0 & 0 & 0 & 0 & 0 & 0 & 0 & 0 & 0 \\
\hline $\begin{array}{l}\text { Farming, fishing, and forestry } \\
\text { occupations }\end{array}$ & 0 & 0 & 0 & 0 & 0 & 0 & 0 & 0 & 0 & 0 \\
\hline $\begin{array}{l}\text { Construction and extraction } \\
\text { occupations }\end{array}$ & 0 & 0 & 0 & 0 & 0 & 0 & 0 & 0 & 0 & 0 \\
\hline $\begin{array}{l}\text { Installation, maintenance, and } \\
\text { repair occupations }\end{array}$ & 0.1 & 0.1 & 0.1 & 0 & 0 & 0 & 0 & 0 & 0 & 0 \\
\hline Production occupations & 0 & 0 & 0 & 0 & 0 & 0 & 0 & 0 & 0 & 0 \\
\hline Transportation occupations & 0 & 0 & 0 & 0 & 0 & 0 & 0 & 0 & 0 & 0 \\
\hline Material moving occupations & 0 & 0 & 0 & 0 & 0 & 0 & 0 & 0 & 0 & 0 \\
\hline Kid $(<15)$ & 0.1 & 0.1 & 0.1 & 0 & 0 & 0 & 0 & 0 & 0 & 0 \\
\hline
\end{tabular}




\begin{tabular}{|c|c|c|c|c|c|c|c|c|c|}
\hline Occupation group & School.G7 & School.G8 & School.G9 & School.G10 & School.G11 & School.G12 & School.G13 & School.G14 & School.G15 \\
\hline None & 0 & 0 & 0 & 0 & 0 & 0 & 0 & 0 & 0 \\
\hline Management occupations & 0 & 0 & 0 & 0 & 0 & 0 & 0 & 0 & 0 \\
\hline $\begin{array}{l}\text { Business and financial } \\
\text { operations occupations }\end{array}$ & 0 & 0 & 0 & 0 & 0 & 0 & 0 & 0 & 0 \\
\hline $\begin{array}{l}\text { Computer and } \\
\text { mathematical } \\
\text { occupations }\end{array}$ & 0 & 0 & 0 & 0 & 0 & 0 & 0 & 0 & 0 \\
\hline $\begin{array}{l}\text { Architecture and } \\
\text { engineering occupations }\end{array}$ & 0 & 0 & 0 & 0 & 0 & 0 & 0 & 0 & 0 \\
\hline $\begin{array}{l}\text { Life, physical, and social } \\
\text { science occupations }\end{array}$ & 0 & 0 & 0 & 0 & 0 & 0 & 0 & 0 & 0 \\
\hline $\begin{array}{l}\text { Community and social } \\
\text { service occupations }\end{array}$ & 0 & 0 & 0 & 0 & 0 & 0 & 0 & 0 & 0 \\
\hline Legal occupations & 0 & 0 & 0 & 0 & 0 & 0 & 0 & 0 & 0 \\
\hline $\begin{array}{l}\text { Educational instruction, } \\
\text { and library occupations }\end{array}$ & 0 & 0 & 0 & 0 & 0 & 0 & 0 & 0 & 0 \\
\hline $\begin{array}{l}\text { Arts, design, } \\
\text { entertainment, sports, } \\
\text { and media occupations }\end{array}$ & 0 & 0 & 0 & 0 & 0 & 0 & 0 & 0 & 0 \\
\hline $\begin{array}{l}\text { Health diagnosing and } \\
\text { treating practitioners and } \\
\text { other technical } \\
\text { occupations; Health } \\
\text { technologists and } \\
\text { technicians }\end{array}$ & 0 & 0 & 0 & 0 & 0 & 0 & 0 & 0 & 0 \\
\hline $\begin{array}{l}\text { Healthcare support } \\
\text { occupations }\end{array}$ & 0 & 0 & 0 & 0 & 0 & 0 & 0 & 0 & 0 \\
\hline $\begin{array}{l}\text { Firefighting and } \\
\text { prevention, and other } \\
\text { protective service } \\
\text { workers including } \\
\text { supervisors; Law } \\
\text { enforcement workers } \\
\text { including supervisors }\end{array}$ & 0 & 0 & 0 & 0 & 0 & 0 & 0 & 0 & 0 \\
\hline $\begin{array}{l}\text { Food preparation and } \\
\text { serving related }\end{array}$ & 0 & 0 & 0 & 0 & 0 & 0 & 0 & 0 & 0 \\
\hline
\end{tabular}




\begin{tabular}{|c|c|c|c|c|c|c|c|c|c|}
\hline $\begin{array}{l}\text { Building and grounds } \\
\text { cleaning and } \\
\text { maintenance occupations }\end{array}$ & 0 & 0 & 0 & 0 & 0 & 0 & 0 & 0 & 0 \\
\hline $\begin{array}{l}\text { Personal care and service } \\
\text { occupations }\end{array}$ & 0 & 0 & 0 & 0 & 0 & 0 & 0 & 0 & 0 \\
\hline $\begin{array}{l}\text { Sales and related } \\
\text { occupations }\end{array}$ & 0 & 0 & 0 & 0 & 0 & 0 & 0 & 0 & 0 \\
\hline $\begin{array}{l}\text { Office and administrative } \\
\text { support occupations }\end{array}$ & 0 & 0 & 0 & 0 & 0 & 0 & 0 & 0 & 0 \\
\hline $\begin{array}{l}\text { Farming, fishing, and } \\
\text { forestry occupations }\end{array}$ & 0 & 0 & 0 & 0 & 0 & 0 & 0 & 0 & 0 \\
\hline $\begin{array}{l}\text { Construction and } \\
\text { extraction occupations }\end{array}$ & 0 & 0 & 0 & 0 & 0 & 0 & 0 & 0 & $\mathrm{c}$ \\
\hline $\begin{array}{l}\text { Installation, maintenance, } \\
\text { and repair occupations }\end{array}$ & 0 & 0 & 0 & 0 & 0 & 0 & 0 & 0 & c \\
\hline Production occupations & 0 & 0 & 0 & 0 & 0 & 0 & 0 & 0 & 0 \\
\hline $\begin{array}{l}\text { Transportation } \\
\text { occupations }\end{array}$ & 0 & 0 & 0 & 0 & 0 & 0 & 0 & 0 & c \\
\hline $\begin{array}{l}\text { Material moving } \\
\text { occupations }\end{array}$ & 0 & 0 & 0 & 0 & 0 & 0 & 0 & 0 & 0 \\
\hline Kid & 0 & 0 & 0 & 0 & 0 & 0 & 0 & 0 & 0 \\
\hline
\end{tabular}

(Continued) 


\begin{tabular}{|c|c|c|c|c|c|c|c|c|}
\hline Occupation group & School.G16 & School.0 & Workplace.s & Workplace.m & Workplace.I & Retail.grocery & Retail.other.s & Retail.other.m \\
\hline None & 0 & 0.2 & 0.1 & 0.1 & 0.1 & 0 & 0 & 0 \\
\hline Management occupations & 0 & 0 & 0.4 & 0.4 & 0.2 & 0 & 0 & 0 \\
\hline $\begin{array}{l}\text { Business and financial } \\
\text { operations occupations }\end{array}$ & 0 & 0 & 0.2 & 0.3 & 0.2 & 0 & 0 & 0 \\
\hline $\begin{array}{l}\text { Computer and mathematical } \\
\text { occupations }\end{array}$ & 0 & 0.2 & 0.1 & 0.2 & 0.4 & 0 & 0 & 0 \\
\hline $\begin{array}{l}\text { Architecture and engineering } \\
\text { occupations }\end{array}$ & 0 & 0.1 & 0.2 & 0.3 & 0.3 & 0 & 0 & 0 \\
\hline $\begin{array}{l}\text { Life, physical, and social } \\
\text { science occupations }\end{array}$ & 0 & 0.2 & 0.3 & 0.2 & 0.2 & 0 & 0 & 0 \\
\hline $\begin{array}{l}\text { Community and social service } \\
\text { occupations }\end{array}$ & 0 & 0 & 0.1 & 0.2 & 0.2 & 0 & 0 & 0 \\
\hline Legal occupations & 0 & 0 & 0.2 & 0.3 & 0.3 & 0 & 0 & 0 \\
\hline $\begin{array}{l}\text { Educational instruction, and } \\
\text { library occupations }\end{array}$ & 0 & 0.35 & 0 & 0 & 0 & 0 & 0 & 0 \\
\hline $\begin{array}{l}\text { Arts, design, entertainment, } \\
\text { sports, and media occupations }\end{array}$ & 0 & 0.1 & 0 & 0 & 0 & 0 & 0 & 0 \\
\hline $\begin{array}{l}\text { Health diagnosing and treating } \\
\text { practitioners and other } \\
\text { technical occupations; Health } \\
\text { technologists and technicians }\end{array}$ & 0 & 0 & 0.5 & 0.5 & 0 & 0 & 0 & 0 \\
\hline $\begin{array}{l}\text { Healthcare support } \\
\text { occupations }\end{array}$ & 0 & 0 & 0.2 & 0.4 & 0.4 & 0 & 0 & 0 \\
\hline $\begin{array}{l}\text { Firefighting and prevention, } \\
\text { and other protective service } \\
\text { workers including supervisors; } \\
\text { Law enforcement workers } \\
\text { including supervisors }\end{array}$ & 0 & 0 & 0.2 & 0.4 & 0.2 & 0 & 0 & 0 \\
\hline $\begin{array}{l}\text { Food preparation and serving } \\
\text { related occupations }\end{array}$ & 0 & 0 & 0.1 & 0 & 0 & 0 & 0 & 0 \\
\hline $\begin{array}{l}\text { Building and grounds cleaning } \\
\text { and maintenance occupations }\end{array}$ & 0 & 0.2 & 0.1 & 0.2 & 0.1 & 0 & 0 & 0 \\
\hline $\begin{array}{l}\text { Personal care and service } \\
\text { occupations }\end{array}$ & 0 & 0 & 0 & 0 & 0 & 0 & 0.2 & 0.4 \\
\hline Sales and related occupations & 0 & 0 & 0 & 0 & 0 & 0.1 & 0.1 & 0.1 \\
\hline
\end{tabular}




\begin{tabular}{|l|c|c|c|c|c|c|c|}
$\begin{array}{l}\text { Office and administrative } \\
\text { support occupations }\end{array}$ & 0 & 0 & 0.13 & 0.44 & 0.33 & 0 \\
\hline $\begin{array}{l}\text { Farming, fishing, and forestry } \\
\text { occupations }\end{array}$ & 0 & 0 & 0 & 0 & 0 & 0 \\
\hline $\begin{array}{l}\text { Construction and extraction } \\
\text { occupations }\end{array}$ & 0 & 0 & 0 & 0 & 0.2 & 0 \\
\hline $\begin{array}{l}\text { Installation, maintenance, and } \\
\text { repair occupations }\end{array}$ & 0 & 0.1 & 0.1 & 0.1 & 0.1 & 0 \\
\hline Production occupations & 0 & 0 & 0 & 0 & 0 & 0 \\
\hline Transportation occupations & 0 & 0 & 0 & 0 & 0 & 0 \\
\hline Material moving occupations & 0 & 0 & 0 & 0 & 0 & 0 \\
\hline Kid & 0 & 0.7 & 0 & 0 & 0 & 0 \\
\hline
\end{tabular}




\begin{tabular}{|c|c|c|c|c|c|c|}
\hline Occupation group & Retail.other.I & PubT.bus & PubT.taxi & PerT & IndoorBnR & Outdoor \\
\hline None & 0 & 0 & 0 & 0 & 0 & 0 \\
\hline Management occupations & 0 & 0 & 0 & 0 & 0 & 0 \\
\hline $\begin{array}{l}\text { Business and financial } \\
\text { operations occupations }\end{array}$ & 0 & 0 & 0 & 0 & 0 & 0 \\
\hline $\begin{array}{l}\text { Computer and } \\
\text { mathematical occupations }\end{array}$ & 0 & 0 & 0 & 0 & 0 & 0 \\
\hline $\begin{array}{l}\text { Architecture and } \\
\text { engineering occupations }\end{array}$ & 0 & 0 & 0 & 0 & 0 & 0 \\
\hline $\begin{array}{l}\text { Life, physical, and social } \\
\text { science occupations }\end{array}$ & 0 & 0 & 0 & 0 & 0 & 0 \\
\hline $\begin{array}{l}\text { Community and social } \\
\text { service occupations }\end{array}$ & 0 & 0 & 0 & 0 & 0 & 0 \\
\hline Legal occupations & 0 & 0 & 0 & 0 & 0 & 0 \\
\hline $\begin{array}{l}\text { Educational instruction, } \\
\text { and library occupations }\end{array}$ & 0 & 0 & 0 & 0 & 0 & 0 \\
\hline $\begin{array}{l}\text { Arts, design, entertainment, } \\
\text { sports, and media } \\
\text { occupations }\end{array}$ & 0 & 0 & 0 & 0 & 0 & 0 \\
\hline $\begin{array}{l}\text { Health diagnosing and } \\
\text { treating practitioners and } \\
\text { other technical } \\
\text { occupations; Health } \\
\text { technologists and } \\
\text { technicians }\end{array}$ & 0 & 0 & 0 & 0 & 0 & 0 \\
\hline $\begin{array}{l}\text { Healthcare support } \\
\text { occupations }\end{array}$ & 0 & 0 & 0 & 0 & 0 & 0 \\
\hline $\begin{array}{l}\text { Firefighting and prevention, } \\
\text { and other protective } \\
\text { service workers including } \\
\text { supervisors; Law } \\
\text { enforcement workers } \\
\text { including supervisors }\end{array}$ & 0 & 0 & 0 & 0.2 & 0 & 0 \\
\hline $\begin{array}{l}\text { Food preparation and } \\
\text { serving related occupations }\end{array}$ & 0 & 0 & 0 & 0 & 0.7 & 0.2 \\
\hline
\end{tabular}




\begin{tabular}{|c|c|c|c|c|c|c|}
\hline $\begin{array}{l}\text { Building and grounds } \\
\text { cleaning and maintenance } \\
\text { occupations }\end{array}$ & 0 & 0 & 0 & 0 & 0 & 0.4 \\
\hline $\begin{array}{l}\text { Personal care and service } \\
\text { occupations }\end{array}$ & 0.4 & 0 & 0 & 0 & 0 & 0 \\
\hline $\begin{array}{l}\text { Sales and related } \\
\text { occupations }\end{array}$ & 0.1 & 0.1 & 0.1 & 0.2 & 0.2 & 0 \\
\hline $\begin{array}{l}\text { Office and administrative } \\
\text { support occupations }\end{array}$ & 0 & 0 & 0 & 0 & 0 & 0 \\
\hline $\begin{array}{l}\text { Farming, fishing, and } \\
\text { forestry occupations }\end{array}$ & 0 & 0 & 0 & 0 & 0 & 1 \\
\hline $\begin{array}{l}\text { Construction and } \\
\text { extraction occupations }\end{array}$ & 0 & 0 & 0 & 0 & 0 & 0.7 \\
\hline $\begin{array}{l}\text { Installation, maintenance, } \\
\text { and repair occupations }\end{array}$ & 0.1 & 0 & 0 & 0 & 0 & 0 \\
\hline Production occupations & 0 & 0 & 0 & 0 & 0 & 0 \\
\hline Transportation occupations & 0 & 0.2 & 0.3 & 0.5 & 0 & 0 \\
\hline $\begin{array}{l}\text { Material moving } \\
\text { occupations }\end{array}$ & 0 & 0 & 0 & 1 & 0 & 0 \\
\hline Kid & 0 & 0 & 0 & 0 & 0 & 0 \\
\hline
\end{tabular}




\begin{tabular}{|c|c|c|c|c|c|c|}
\hline Occupation group & OtherL.s & OtherL.m & OtherL.I & OtherS.s & OtherS.m & OtherS.I \\
\hline None & 0 & 0.2 & 0 & 0 & 0 & 0 \\
\hline Management occupations & 0 & 0 & 0 & 0 & 0 & 0 \\
\hline Business and financial operations occupations & 0 & 0 & 0 & 0.2 & 0.1 & 0 \\
\hline Computer and mathematical occupations & 0 & 0 & 0 & 0 & 0 & 0 \\
\hline Architecture and engineering occupations & 0 & 0 & 0 & 0 & 0 & 0 \\
\hline Life, physical, and social science occupations & 0 & 0 & 0 & 0 & 0 & 0 \\
\hline Community and social service occupations & 0 & 0 & 0 & 0.1 & 0.2 & 0.2 \\
\hline Legal occupations & 0 & 0 & 0 & 0 & 0 & 0 \\
\hline Educational instruction, and library occupations & 0 & 0 & 0.02 & 0 & 0 & 0 \\
\hline $\begin{array}{l}\text { Arts, design, entertainment, sports, and media } \\
\text { occupations }\end{array}$ & 0.2 & 0.3 & 0.3 & 0 & 0 & 0 \\
\hline $\begin{array}{l}\text { Health diagnosing and treating practitioners and other } \\
\text { technical occupations; Health technologists and } \\
\text { technicians }\end{array}$ & 0 & 0 & 0 & 0 & 0 & 0 \\
\hline Healthcare support occupations & 0 & 0 & 0 & 0 & 0 & 0 \\
\hline $\begin{array}{l}\text { Firefighting and prevention, and other protective service } \\
\text { workers including supervisors; Law enforcement workers } \\
\text { including supervisors }\end{array}$ & 0 & 0 & 0 & 0 & 0 & 0 \\
\hline Food preparation and serving related occupations & 0 & 0 & 0 & 0 & 0 & 0 \\
\hline $\begin{array}{l}\text { Building and grounds cleaning and maintenance } \\
\text { occupations }\end{array}$ & 0 & 0 & 0 & 0 & 0 & 0 \\
\hline Personal care and service occupations & 0 & 0 & 0 & 0 & 0 & 0 \\
\hline Sales and related occupations & 0 & 0 & 0 & 0 & 0 & 0 \\
\hline Office and administrative support occupations & 0 & 0.02 & 0.02 & 0 & 0.03 & 0.03 \\
\hline Farming, fishing, and forestry occupations & 0 & 0 & 0 & 0 & 0 & 0 \\
\hline Construction and extraction occupations & 0 & 0.1 & 0 & 0 & 0 & 0 \\
\hline
\end{tabular}




\begin{tabular}{|c|c|c|c|c|c|c|}
\hline Installation, maintenance, and repair occupations & 0 & 0 & 0 & 0 & 0 & 0 \\
\hline Production occupations & 0 & 0.45 & 0.55 & 0 & 0 & 0 \\
\hline Transportation occupations & 0 & 0 & 0 & 0 & 0 & 0 \\
\hline Material moving occupations & 0 & 0 & 0 & 0 & 0 & 0 \\
\hline Kid & 0 & 0 & 0 & 0 & 0 & 0 \\
\hline
\end{tabular}




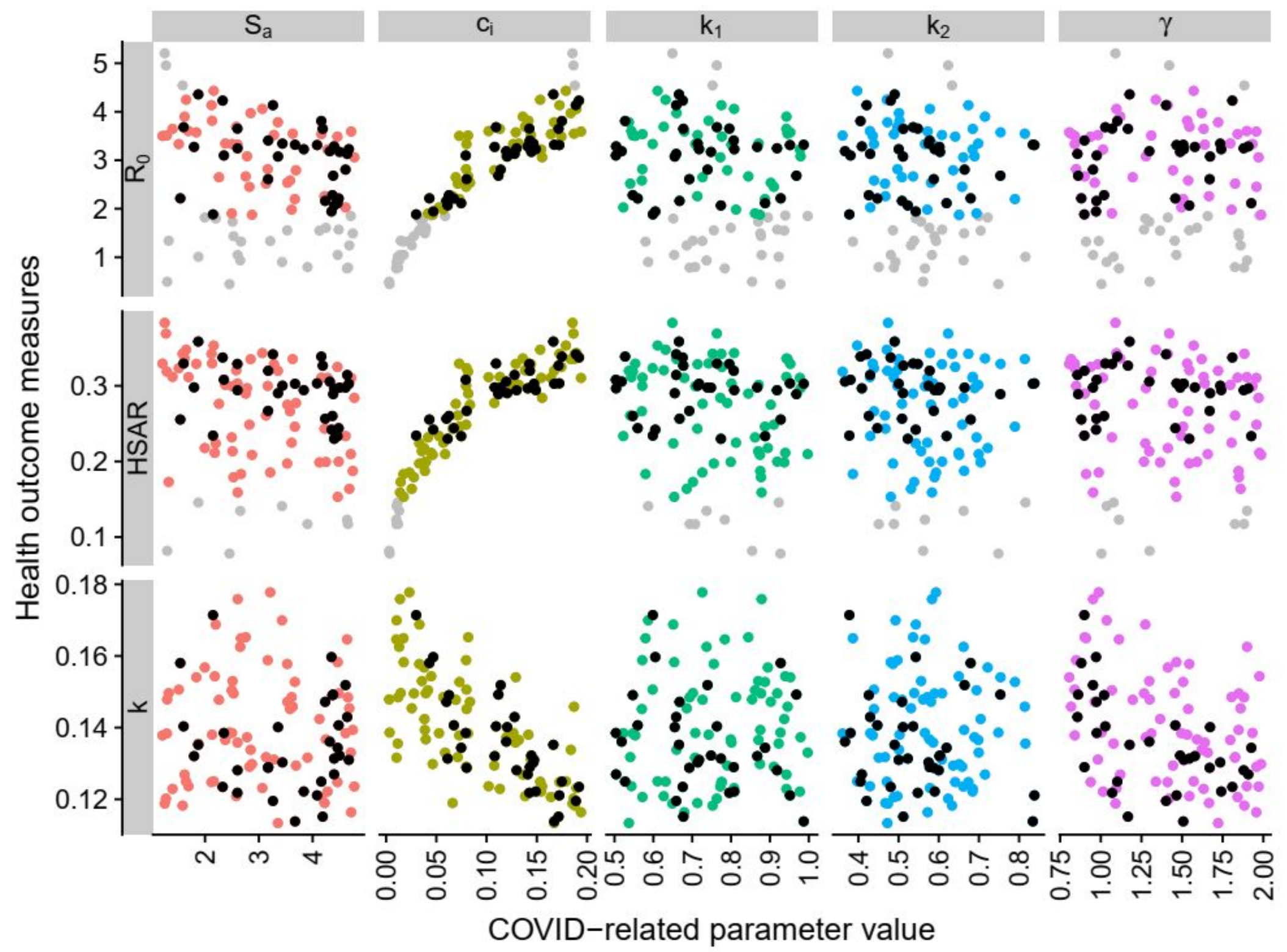

Figure S1. Scatterplots of calibrated parameters and the health outcome measures. Colored and black dots represent parameter sets that match the criteria defined in Methods, with black dots representing 32 parameter sets sampled for further simulations. 

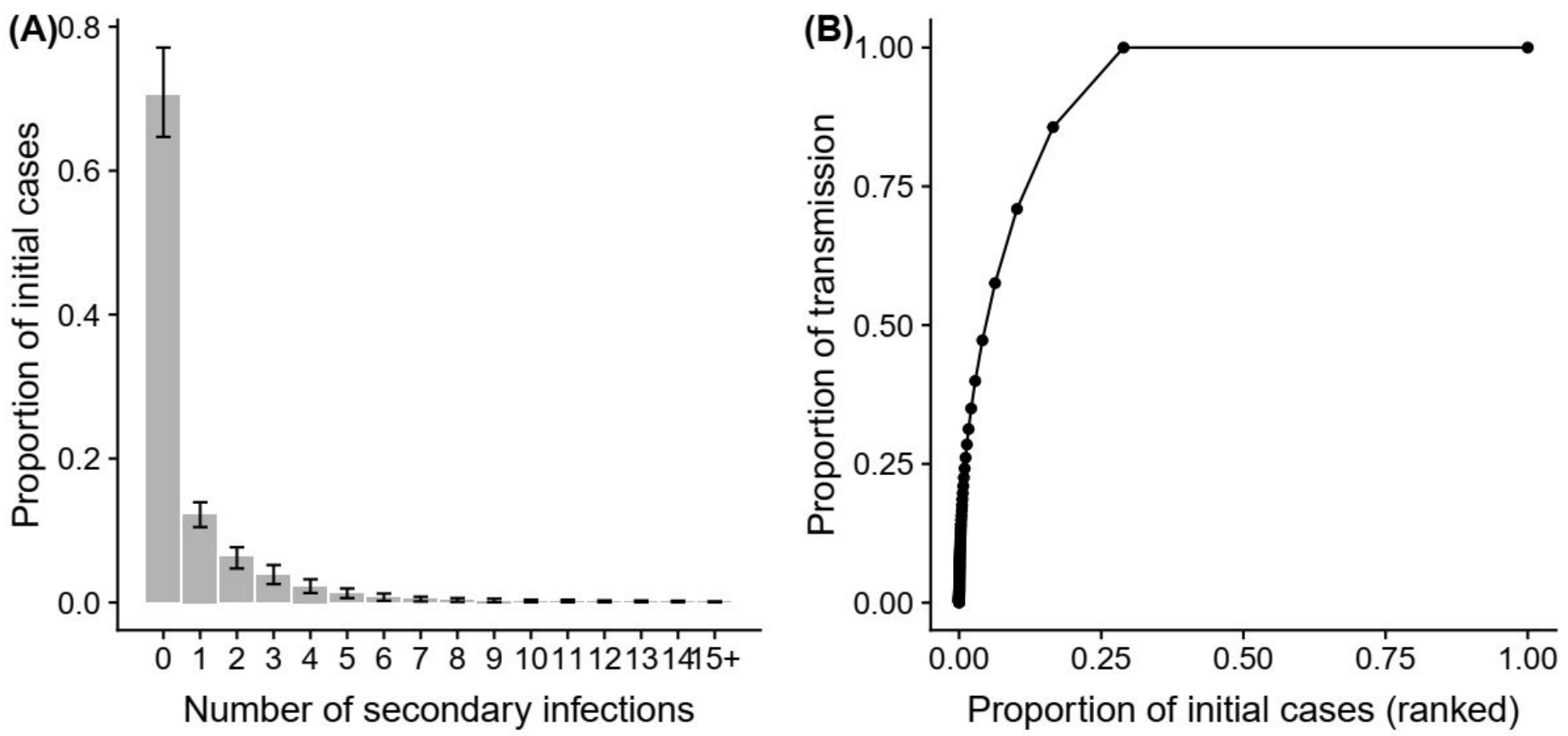

Figure S2. Variation in the number of secondary infections caused by initial cases. (A) Distribution of the number of secondary infections caused by initial cases. Bars represent the mean value in 320 simulations, while error bars represent the $95 \% \mathrm{Cl}$. (B) Proportion of transmission due to proportion of initial cases ranked by infectiousness in all 320 simulations. 
(A) Age

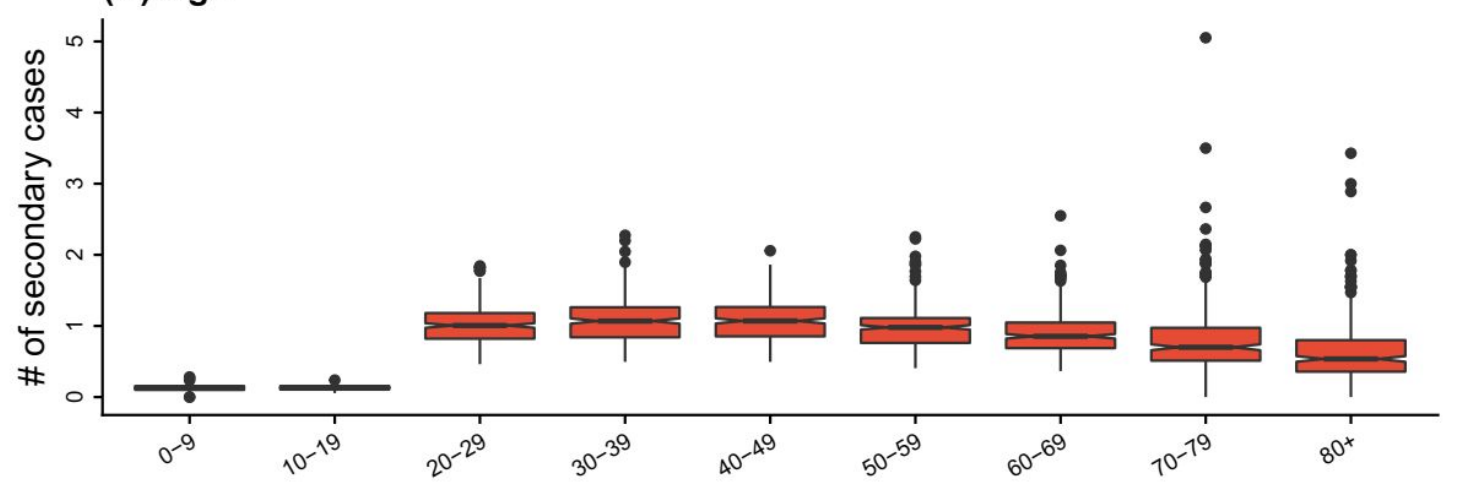

(B) Sex

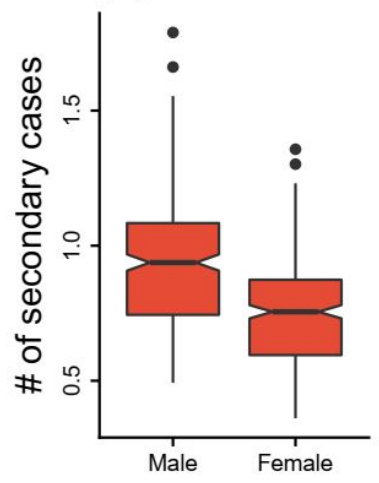

(C) Household size

(D) Household income

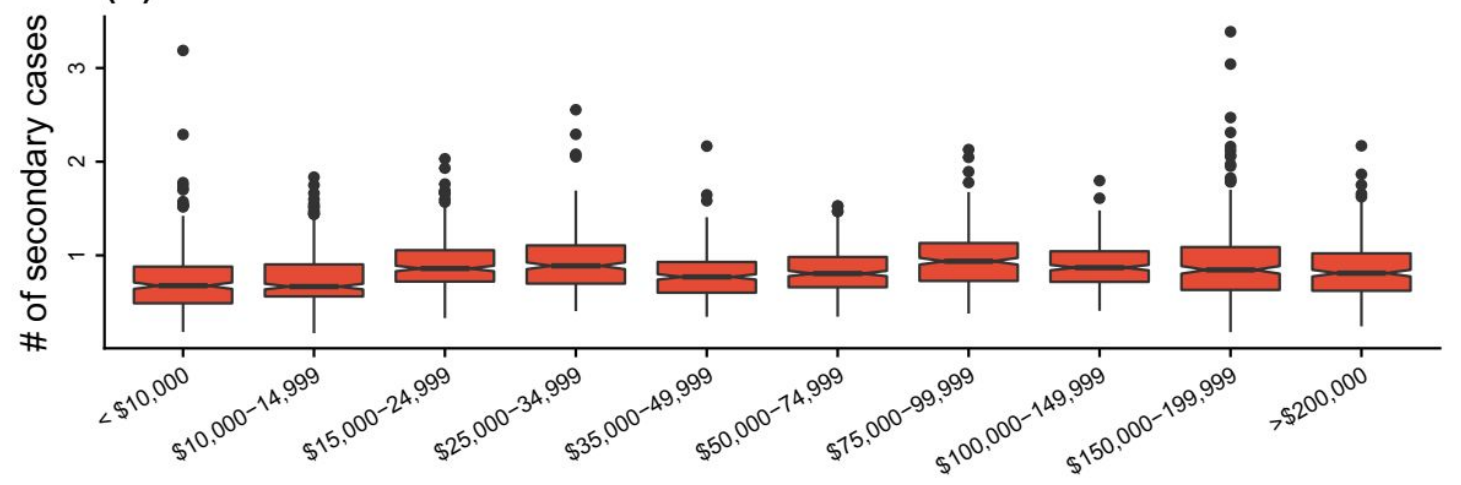

(E) Occupation

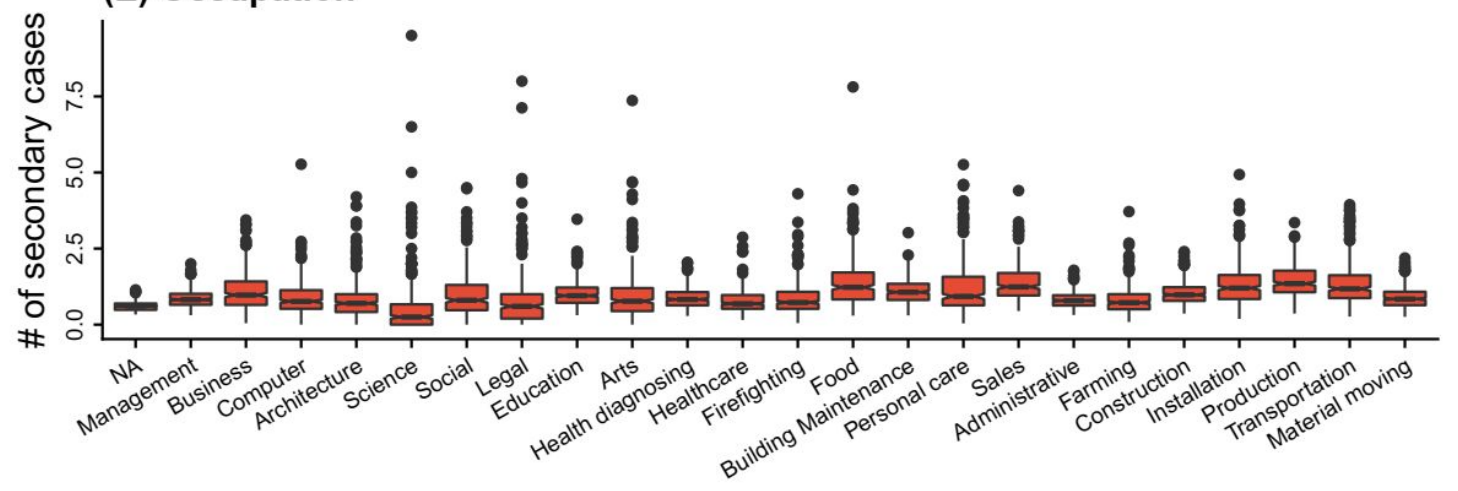

Figure S3. Number of secondary cases caused by initial cases in each (A) age, (B) sex, (C) household size, (D) household income, and (E) occupation categories. 

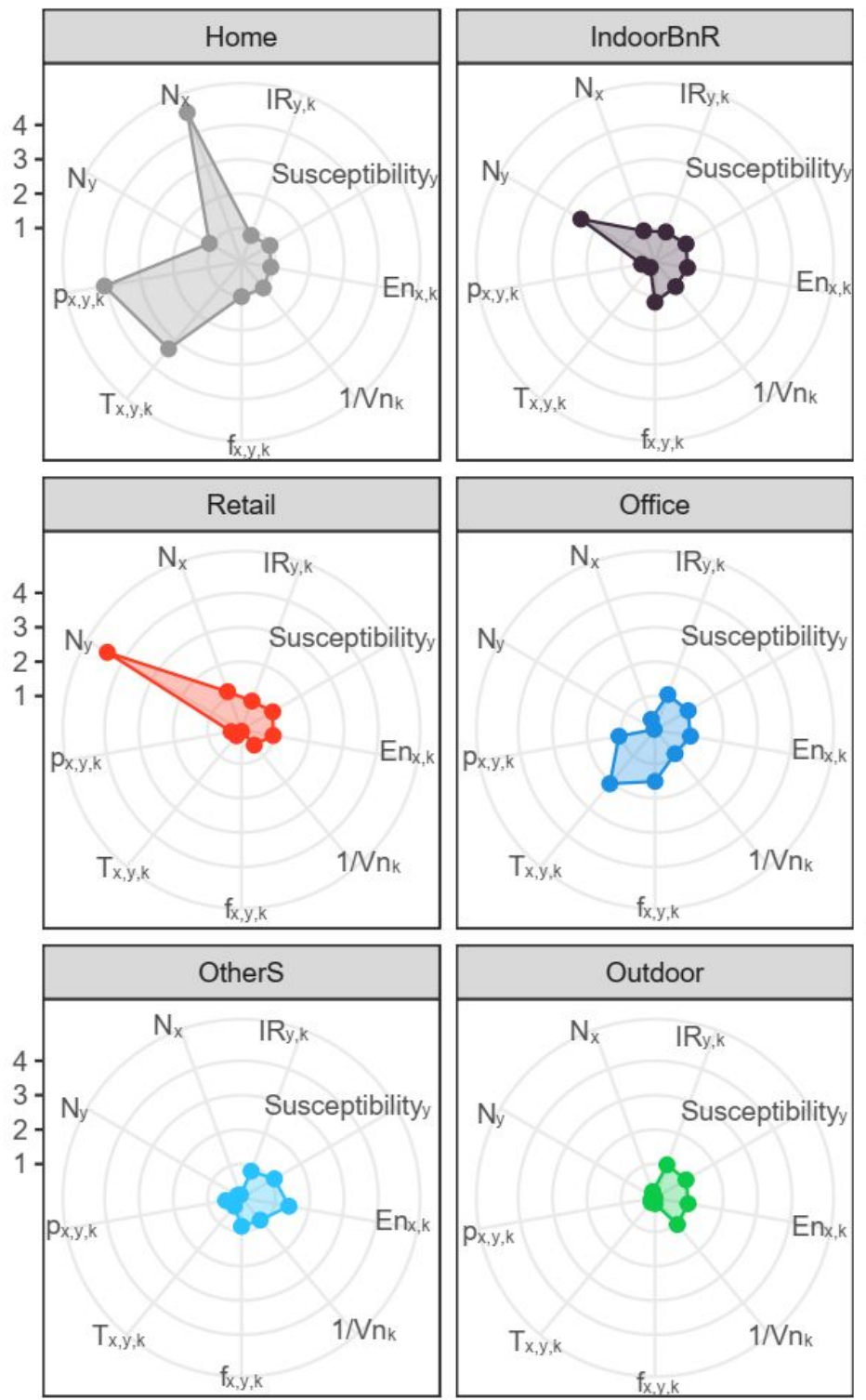
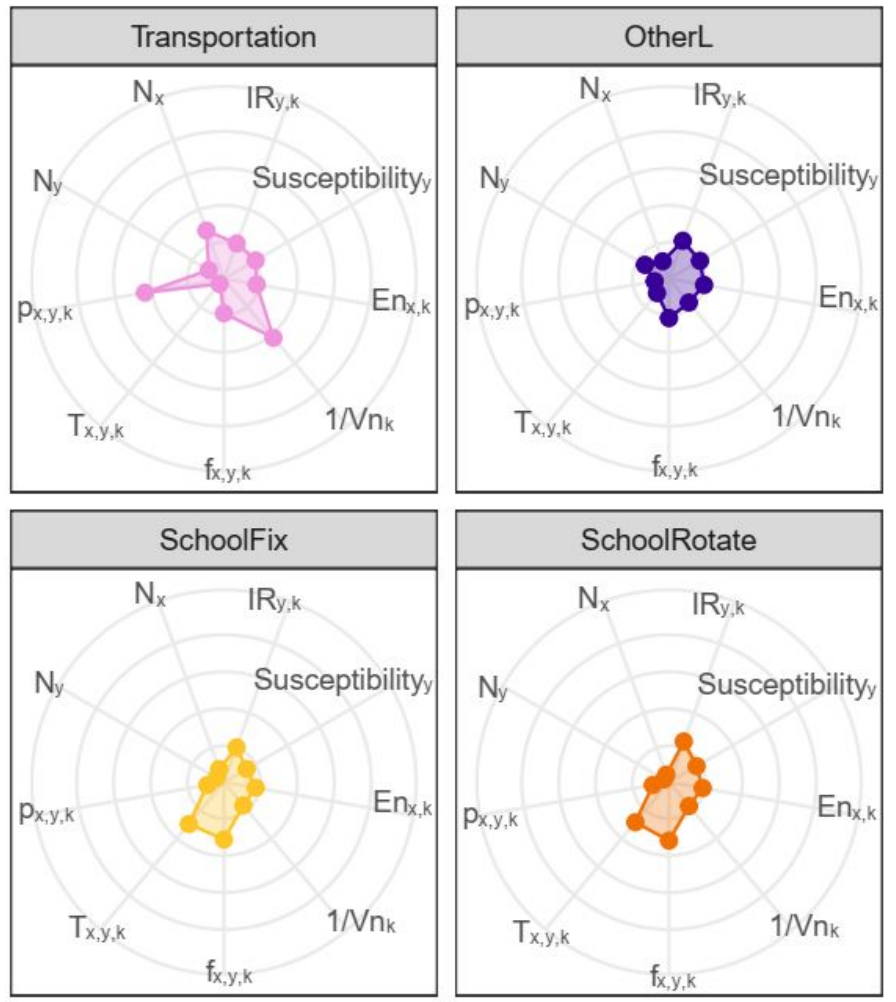

Figure S4. Determinants of infection risk through near-field exposure. The radial value for each dimension, measured by the scale on the $\mathrm{Y}$-axis shows the mean (median for $E n_{x, k}$ ) value across all specific environments in that category, standardized by the mean of all specific environments. $I R_{\mathrm{y}, \mathrm{k}}$ : inhalation rate of susceptibles in the environment; Susceptibility $\mathrm{y}_{\mathrm{y}}$ susceptibility of the susceptibles; $\mathrm{n}_{\mathrm{x}, \mathrm{k}}$ : quanta emission rate of initial cases; $V_{n x}$ : volume of the near field in the environment; $f_{x, y, k}$ : proportion of overlapping time between initial cases and susceptibles in the near field given close contact; $T_{x, y, k}:$ overlapping time between initial cases and susceptibles; $p_{x, y, k}$ : probability of near-field exposure between initial cases and susceptibles; $N_{y}$ : number of susceptibles visiting the environment; $\mathrm{Nx}$ : number of initial cases visiting the environment. 

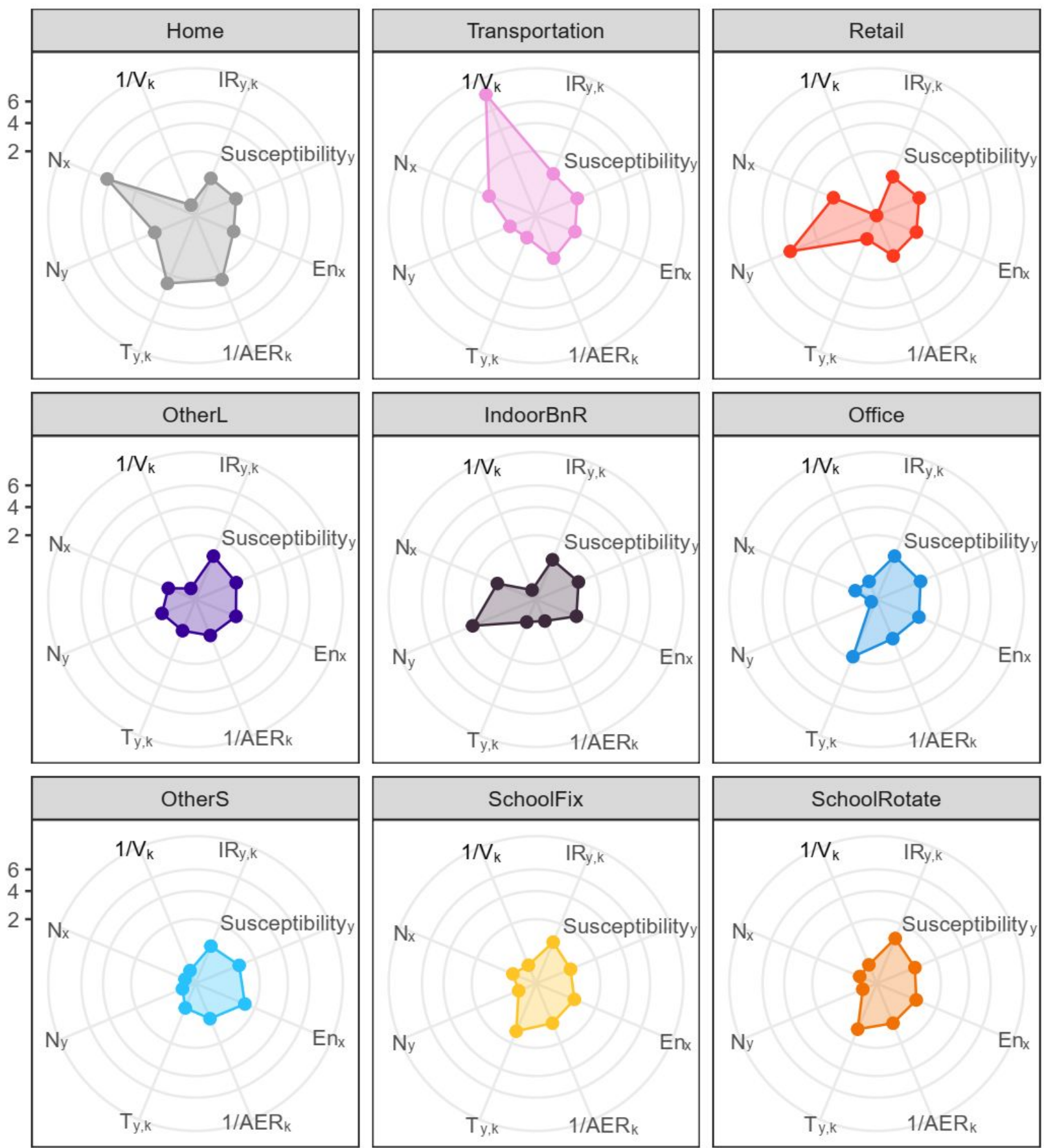

Figure S5. Determinants of infection risk through far-field exposure. The radial value for each dimension, measured by the scale on the $\mathrm{Y}$-axis shows the mean (median for $E \mathrm{n}_{\mathrm{x}, \mathrm{k}}$ ) value across all specific environments in that category, standardized by the mean of all specific environments. $I_{\mathrm{y}, \mathrm{k}}$ : inhalation rate of susceptibles in the environment; Susceptibility $\mathrm{y}_{\mathrm{y}}$ susceptibility of the susceptibles; $\mathrm{n}_{\mathrm{x}, \mathrm{k}}$ : quanta emission rate of initial cases; $A E R_{k}$ : air exchange rate; $T_{y, k}$ : time spent by the susceptibles in the environment; $N_{y}$ : number of susceptibles visiting the environment; Nx: number of initial cases visiting the environment; $\mathrm{V}_{\mathrm{k}}$ : volume of the environment. 


\section{References}

1. Ye, X.; Konduri, K.; Pendyala, R. M.; Sana, B.; Waddell, P. In A methodology to match distributions of both household and person attributes in the generation of synthetic populations, 88th Annual Meeting of the Transportation Research Board, Washington, DC, 2009.

2. Ward, K. ipfr: List Balancing for Reweighting and Population Synthesis. R package version 1.0.2. https://github.com/dkyleward/ipfr.

3. Health, U. S. E. P. A. O. o.; Group, E. A. E. A., Exposure factors handbook. Office of Health and Environmental Assessment, US Environmental Protection ...: 1989; Vol. 90.

4. United States Department of Labor American Time Use Survey-2003-2019 Microdata files. https://www.bls.gov/tus/ (accessed 2020-05-01).

$5 . \quad$ Institute for Social Research, U. o. M. Panel Study of Income Dynamics. https://psidonline.isr.umich.edu/ (accessed May 1st).

6. Schaller, B., A regression model of the number of taxicabs in US cities. Journal of Public Transportation 2005, 8 (5), 4.

7. $\quad$ Chamie, G.; Marquez, C.; Crawford, E.; Peng, J.; Petersen, M.; Schwab, D.; Schwab, J.; Martinez, J.; Jones, D.; Black, D., Community transmission of severe acute respiratory syndrome coronavirus 2 disproportionately affects the Latinx population during shelter-in-place in San Francisco. Clinical Infectious Diseases 2020.

8. $\quad$ Poletti, P.; Tirani, M.; Cereda, D.; Trentini, F.; Guzzetta, G.; Marziano, V.; Buoro, S.; Riboli, S.; Crottogini, L.; Piccarreta, R., Age-specific SARS-CoV-2 infection fatality ratio and associated risk factors, Italy, February to April 2020. Eurosurveillance 2020, 25 (31), 2001383.

9. Moghadas, S. M.; Fitzpatrick, M. C.; Sah, P.; Pandey, A.; Shoukat, A.; Singer, B. H.; Galvani, A. P., The implications of silent transmission for the control of COVID-19 outbreaks. Proceedings of the National Academy of Sciences 2020, 117 (30), 17513-17515.

10. Shakya, K. M.; Noyes, A.; Kallin, R.; Peltier, R. E., Evaluating the efficacy of cloth facemasks in reducing particulate matter exposure. Journal of exposure science \& environmental epidemiology 2017, 27 (3), 352-357.

11. Lindsley, W. G.; Blachere, F. M.; Law, B. F.; Beezhold, D. H.; Noti, J. D., Efficacy of face masks, neck gaiters and face shields for reducing the expulsion of simulated cough-generated aerosols. Aerosol Science and Technology 2021, 55 (4), 449-457.

12. Teesing, G.; van Straten, B.; de Man, P.; Horeman-Franse, T., Is there an adequate alternative to commercially manufactured face masks? A comparison of various materials and forms. Journal of Hospital Infection 2020, 106 (2), 246-253.

13. Zangmeister, C. D.; Radney, J. G.; Vicenzi, E. P.; Weaver, J. L., Filtration efficiencies of nanoscale aerosol by cloth mask materials used to slow the spread of SARS-CoV-2. ACS nano 2020, 14 (7), 9188-9200. 14. Sayampanathan, A. A.; Heng, C. S.; Pin, P. H.; Pang, J.; Leong, T. Y.; Lee, V. J., Infectivity of asymptomatic versus symptomatic COVID-19. The Lancet 2021, 397 (10269), 93-94.

15. Yan, J.; Grantham, M.; Pantelic, J.; De Mesquita, P. J. B.; Albert, B.; Liu, F.; Ehrman, S.; Milton, D. K.; Consortium, E., Infectious virus in exhaled breath of symptomatic seasonal influenza cases from a college community. Proceedings of the National Academy of Sciences 2018, 115 (5), 1081-1086.

16. Buonanno, G.; Stabile, L.; Morawska, L., Estimation of airborne viral emission: Quanta emission rate of SARS-CoV-2 for infection risk assessment. Environment International 2020, 141, 105794.

17. Miller, S. L.; Nazaroff, W. W.; Jimenez, J. L.; Boerstra, A.; Buonanno, G.; Dancer, S. J.; Kurnitski, J.; Marr, L. C.; Morawska, L.; Noakes, C., Transmission of SARS - CoV - 2 by inhalation of respiratory aerosol in the Skagit Valley Chorale superspreading event. Indoor air 2021, 31 (2), 314-323. 